
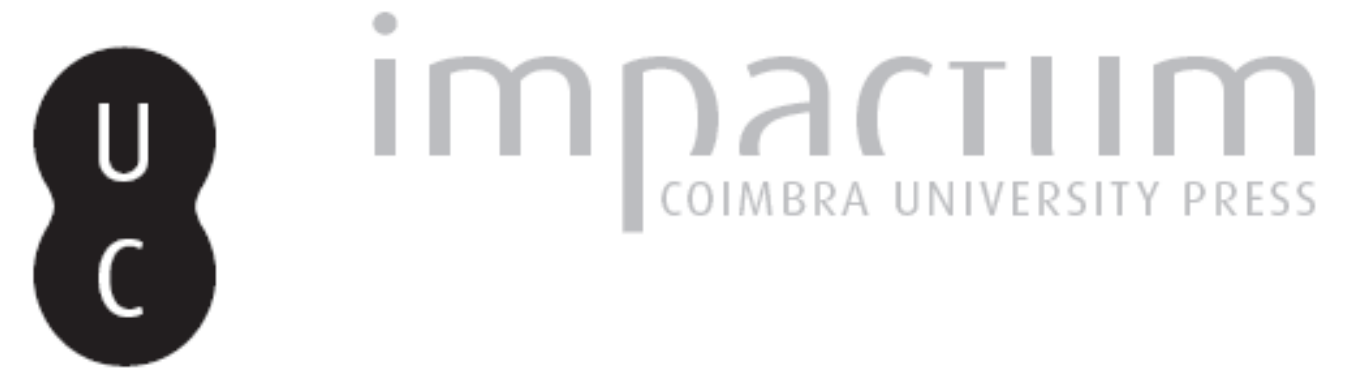

\title{
Dois tratados plotinianos em Eusébio de Cesaréia
}

\section{Autor(es): $\quad$ Goulet-Cazé, Marie-Odile}

Publicado por: Annablume Clássica

URL persistente:

URI:http://hdl.handle.net/10316.2/24472

DOI:

DOI:http://dx.doi.org/10.14195/1984-249X_5_1

Accessed : $\quad$ 26-Apr-2023 12:18:09

A navegação consulta e descarregamento dos títulos inseridos nas Bibliotecas Digitais UC Digitalis, UC Pombalina e UC Impactum, pressupõem a aceitação plena e sem reservas dos Termos e Condições de Uso destas Bibliotecas Digitais, disponíveis em https://digitalis.uc.pt/pt-pt/termos.

Conforme exposto nos referidos Termos e Condições de Uso, o descarregamento de títulos de acesso restrito requer uma licença válida de autorização devendo o utilizador aceder ao(s) documento(s) a partir de um endereço de IP da instituição detentora da supramencionada licença.

Ao utilizador é apenas permitido o descarregamento para uso pessoal, pelo que o emprego do(s) título(s) descarregado(s) para outro fim, designadamente comercial, carece de autorização do respetivo autor ou editor da obra.

Na medida em que todas as obras da UC Digitalis se encontram protegidas pelo Código do Direito de Autor e Direitos Conexos e demais legislação aplicável, toda a cópia, parcial ou total, deste documento, nos casos em que é legalmente admitida, deverá conter ou fazer-se acompanhar por este aviso.

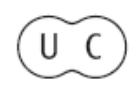



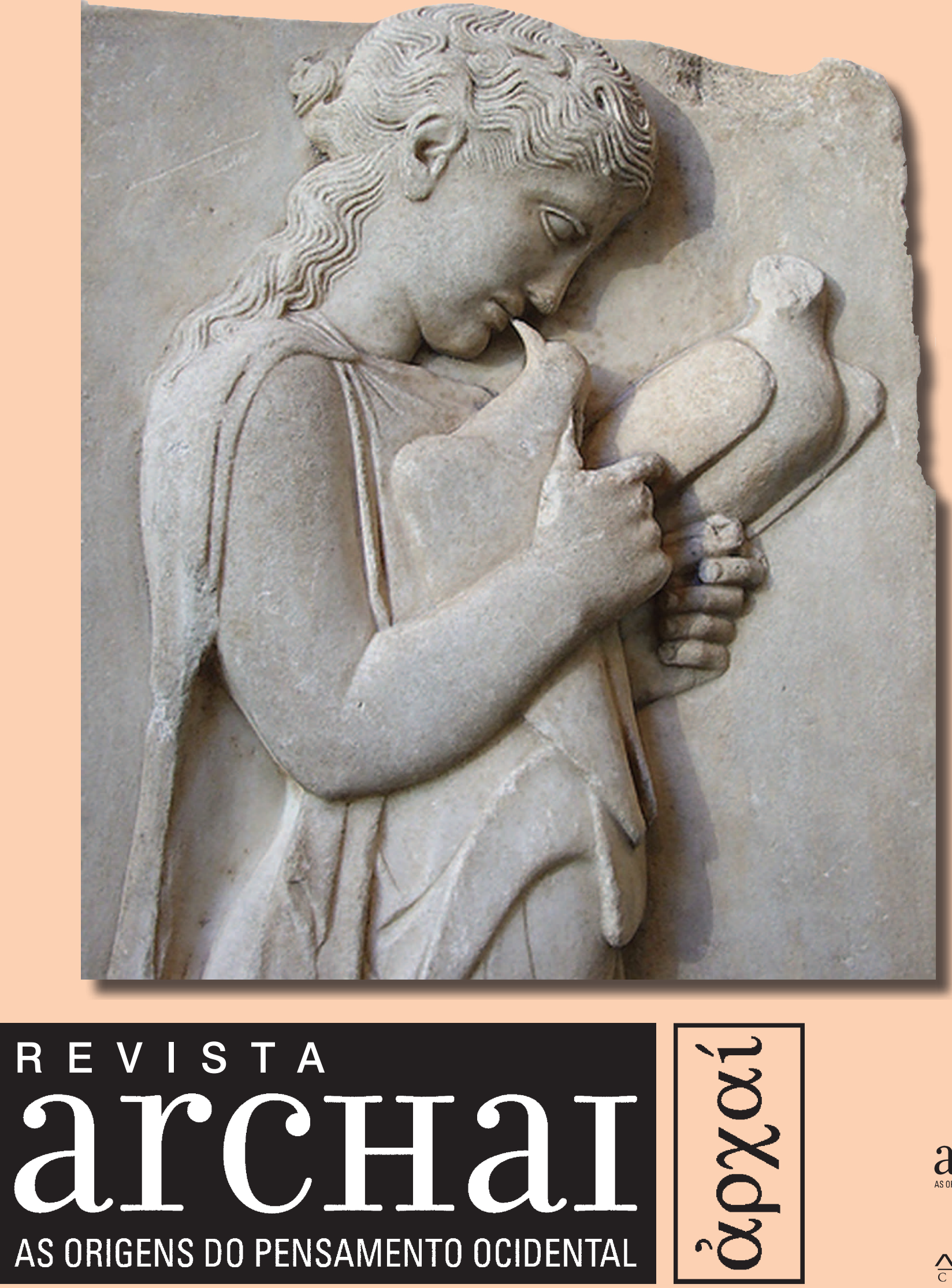


\section{DOIS TRATADOS PLOTINIANOS EM EUSÉBIO DE CESARÉIA ${ }^{1}$}

RESUMO: Eusébio de Cesaréia, na sua Preparação Evangélica, cita um longo trecho do escrito de Plotino ao qual Porfírio, na sua edição das Enéadas, intitulou "Sobre a imortalidade da alma" (IV. 7 [2]). Surpreendentemente, esse trecho citado por Eusébio (hoje em dia editado como os capítulos $8^{1}-8^{5}$ desse tratado) está ausente da edição porfiriana. Tentou-se explicar essa ausência de diversas formas: alguns estudiosos pensam que o texto citado por Eusébio seja um resquício da edição que Eustóquio fizera dos escritos de Plotino; outros, que ele provenha das cópias que Amélio teria levado à Apaméia. Este artigo tentará mostrar que não é possivel sustentar a opinião de que o texto citado por Eusébio provenha de outra edição que não seja a de Porfirio e que a ausência desse trecho da edição porfiriana pode ser explicada por um acidente da tradição direta das Enéadas.

PALAVRAS-CHAVE: Plotinus, Enéadas, Eusébio de Cesaréia, Preparação Evangélica, manuscritos.

ABSTRACT: Eusebius of Cesarea, in his Praeparatio Evangelica, quotes a large piece of Plotinus' writing to which Porphyry, in his edition of the Enneads, gave the title "On the Immortality of Soul" (IV. 7 [2]). Surprisingly, the piece quoted by Eusebius (now edited as chapters $8^{1}-8^{5}$ of that treatise) is absent from the Porphyrian edition. Some reasons for this absence have been adduced: some scholars think that the text quoted by Eusebius might be a trace of the edition of Plotinus's writings made by Eustochius; others think that it might come from the copies Amelius carried to Apameia. This paper will try to show that the opinion that the text quoted by Eusebius come from an edition other than that of Porphyry is hardly defendable, and that the absence of such piece from Porphyry's edition can be explained by an accident on the direct tradition of the Enneads.

KEYWORDS: Plotinus, Enneads, Eusebius of Cesarea, Praeparatio Evangelica, manuscripts.
1. "Deux traités plotiniens chez Eusèbe de Césarée" foi originalmente publicado em Cristina D'Ancona (ed.), The Libraries of the Neoplatonists (Philosophia

Antiqua, volume 107), Leiden-Boston, Brill, 2007

p. 63-97. A tradução é de Loraine Oliveira e José Carlos Baracat Júnior. Agradecemos Marie-Odile Goulet-Cazé por gentilmente nos autorizar a traduzir e republicar ses artigo.

2. Pesquisadora do CNRS (Centre National de la Recherche Scientifique, Villejuif, França).

3. Porfírio os menciona, com efeito, dentre o grupo de tratados escritos por Plotino antes que ele mesmo tenha chegado à sua escola, em 263. Cf. o cap. 4 da Vita Plotini de Porfírio.
Marie-Odile Goulet-Cazé

Os tratados dos filósofos neoplatônicos não permaneciam confinados em suas bibliotecas. Eles podiam circular de uma parte a outra do Mediterrâneo. Cristãos eventualmente tinham acesso a eles, tanto no Oriente como no Ocidente. Eunápio, cujos exageros costumeiros se fundavam sobre uma parte de realidade, chega a declarar que na sua época, nos primeiros anos do Vo século, as "massas" conheciam os escritos de Plotino ainda mais que as obras de Platão. Um dos testemunhos mais importantes da circulação desses tratados é Eusébio de Cesaréia. Três estratos emanando de dois tratados de Plotino: V 1 e IV 7 são, com efeito, citados por Eusébio na sua Preparação evangélica XI 17, XV 10 e 22. Podemos agora nos interrogar sobre o modo como esses dois tratados plotinianos puderam, de Roma, onde Plotino os havia redigido antes de $263^{3}$, chegar a Cesaréia da Palestina, onde Eusébio os tinha entre mãos no início do IV ${ }^{0}$ século, quando compôs os livros XI e XV da sua obra. Mas essas citações suscitam um problema ainda mais interessante, pois dois desses extratos, os tirados de IV 7, estão hoje ausentes da tradição direta das Enéadas. Diversas hipóteses foram aventadas para explicar a origem dessas passagens: segundo alguns, esses extratos teriam sido tomados de empréstimo de uma edição dos tratados de Plotino anterior àquela de Porfírio; 
segundo outros, Eusébio pôde utilizar um texto que remonta aos exemplares privados de um aluno de Plotino, Amélio, que havia emigrado para o Oriente antes da morte de Plotino; segundo outros, enfim, a ausência dessas passagens das Enéadas proviria de um simples acidente da tradição direta.

\section{A hipótese de uma edição de Eustóquio.}

A hipótese que foi por muito tempo aventada supõe que Eusébio tinha em mãos uma edição dos tratados de Plotino devida a um certo Eustóquio ${ }^{4}$, sem dúvida o médico que cuidou de Plotino até a sua morte em 270 e que era o único presente quando da morte do mestre (V.P. 2. 12, 23, 34; 8. 12). Fundamentou-se a existência dessa edição em um escólio à Enéada IV 4, 29. 55, e se supôs que Plotino, no momento da sua morte, pudera ter confiado a Eustóquio o cuidado de reagrupar todos os seus tratados e de editá-los. Eis o texto desse escólio conservado por certos manuscritos de três das grandes famílias de manuscritos das Enéadas: $w(\mathrm{~A}, \mathrm{E}), x(\mathrm{R}, \mathrm{J})$ e $y(\mathrm{C}, \mathrm{M})$ :

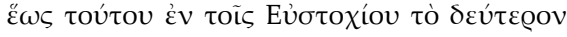

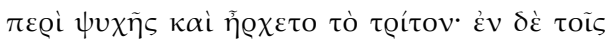

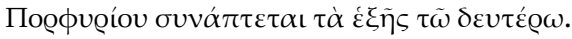

Ia até aqui nos (manuscritos) de Eustóquio o segundo tratado Sobre a alma e neste lugar começava o terceiro tratado. Nos (manuscritos) de Porfíio, ao contrário, o que segue está ligado ao segundo tratado.

Os tratados Sobre a alma em causa no escólio correspondem às Enéadas IV 3, 4 e 5; são tratados que foram redigidos por Plotino enquanto Porfírio estava em Roma, na sua escola, portanto entre 263 e 268 (V.P. 5. 20-25). 0 título que é dado a esses tratados em Eustóquio ( aquele imposto por Porfírio na sua própria edição. Este último, na tabela sistemática ao final da Vita Plotini 25. 16-21, no Pinax precedendo as Enéadas e nas Enéadas elas mesmas, encabeçando os tratados correspondentes, dá a esses tratados os títulos

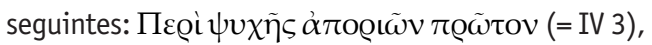

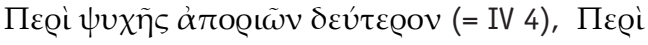

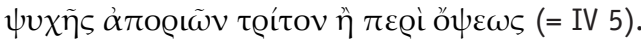
Causa menos surpresa que o título de Eustóquio vá ao encontro daqueles da tabela cronológica da Vita Plotini (5. 20-25) onde lemos: Пع@i $\psi v \chi \tilde{\eta} \varsigma$ $\pi \varrho \tilde{\omega} \tau o v, ~ \Pi \varepsilon \varrho i ~ \psi v \chi \tilde{\eta} \varsigma ~ \delta \varepsilon v ́ \tau \varepsilon \varrho o v, ~ \Pi \varepsilon \varrho i ~ \psi v \chi \tilde{\eta} \varsigma$

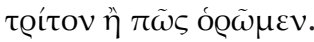

Desse escólio podemos tirar então várias conclusões:

- havia duas realidades literárias compa-ráveis que são postas aqui em paralelo: uma ligada ao nome de Eustóquio, outra ao de Porfírio;

- os títulos podiam ser diferentes nos dois conjuntos;

- certos tratados eram divididos diferentemente em Eustóquio e em Porfírio, pois o terceiro

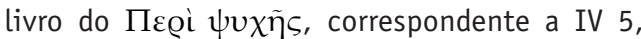
começava antes em Eustóquio do que em Porfírio. $\mathrm{Na}$ versão de Eustóquio, com efeito, o tratado IV 4 terminava no capítulo 29, o que fazia o tratado IV 5 começar no capítulo 30 , enquanto que os capítulos 30 a 45 ainda fazem parte de IV 4 nas Enéadas ${ }^{5}$.

É legítimo a partir desse único escólio concluir uma edição de Eustóquio?

Lembremos que Porfírio não evoca nenhuma edição dos tratados de Plotino anterior à sua. Talvez ele considerasse que somente as Enéadas fossem uma edição digna desse nome e que apenas e unicamente ele era o editor de Plotino, incumbido pelo mestre. Com efeito, Porfírio relata que Plotino havia the confiado o cuidado de assegurar a ordenação e a correção dos seus livros e que ele havia prometido a Plotino, ainda vivo, realizar essa tarefa (V.P. 24 2-3). Curiosamente, aliás, Porfírio só acabará esse trabalho de edição trinta anos após a morte de Plotino ${ }^{6}$.

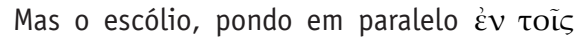

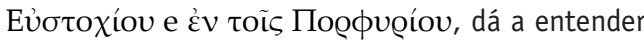
que se trata de duas realidades literárias da mesma ordem, conhecidas por eventuais leitores. No caso de Porfírio trata-se, segundo toda verossimi-lhança, das Enéadas, pois a divisão evocada é aquela que se encontra na edição porfiriana e o escólio está conservado pela tradição direta das Enéadas. No caso de Eustóquio, tratava-se seja de uma verdadeira
4. Sobre a edição de Eustóquio, ver Goulet-Cazé, M.-0, "L'arrièreplan scolaire de la Vie de Plotin", em Brisson, L. et al., Porphyre, La Vie de Plotin, I. Travaux préliminaires et index grec complet, Vrin, Paris, 1982 (Histoire des doctrines de l'Antiquité Classique 6), p. 231-327, notadamente p. 287-94; Brisson, L. “Une édition d'Eustochius? ", em Brisson, L. et al., Porphyre, La Vie de Plotin, II. Vrin, Paris, 1992 (Histoire des doctrines de l'Antiquité Classique 16), p. 63-69; Goulet-Cazé, M.-0, "Remarques sur l'édition d'Eustochius", ibid., p. 71-76.

5. Cf. Henry, États, p. 17.

6. Porfírio tem 30 anos quando chega a Roma em 263 e é em 301, quando está seu sexagésimo oitavo ano (V.P. 23, 21-14), que redige a Vita Plotini, a qual servirá de preâmbulo às Enéadas; todavia Plotino faleceu em 270. 
7. Brisson, "Une édition d'Eustochius?", p. 63-69, considera no entanto que Amélio havia realmente feito uma edição dos tratados de Plotino.

8. Se pensamos que existia realmente uma edição préporfiriana dos tratados de Plotino, somos constrangidos, em razão do paralelo estabelecido pelo escólio evocado acima, a reconhecer que somente a versão de Eustóquio poderia eventualmente pretender esse título.

9. P. Henry, recherches sur la Préparation évangélique d'Eusèbe et l'édition perdue des oeuvres de Plotin publiée par Eustochius, Leroux, Paris, 1935 (Bibliothèque

de l'École des Hautes Études. Sciences religieuses 50), p. 73-79. edição (mas, por outro lado, ela não é atestada em nenhum lugar e ignoramos se era uma verdadeira edição com o trabalho de correção que tal empresa supõe), seja simplesmente de uma recensão diferente dos tratados plotinianos (não sabemos se esta era completa ou parcial: Eustóquio pôde ter acesso a todos os tratados de Plotino quando da morte deste?). Eustóquio pôde somente reagrupar todos os tratados que estavam em sua posse à morte do mestre e que circulavam na escola sob títulos divergentes (V.P. 4. 16-18). Um caso análogo é fornecido pelos exemplares copiados por Amélio dos originais de Plotino (cf. V. P. 20. 6: غ่к $\tau \tilde{\omega} \nu$ A $\mu \varepsilon \lambda$ íov; 20. 8: $\tau \dot{\alpha} \pi \alpha Q^{\prime}$ A $\mu \varepsilon \lambda$ íov). Este discípulo de Plotino os levou, aliás, ao Oriente e permitiu que Longino mandasse fazer cópias deles. Falar de edição, em tal caso, como se fez eventualmente ${ }^{7}$, é ultrapassar o alcance dos testemunhos ${ }^{8}$. 0 fato de Porfírio em V.P. 4. 14-15 empregar o particípio

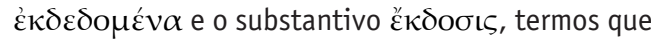
muito freqüentemente remetem a uma realidade editorial, não implica tampouco a existência de uma edição pré-porfiriana dos tratados plotinianos. Esses termos, no contexto, não aludem a uma edição. Porfírio está falando dos vinte e um livros escritos por Plotino antes que ele próprio chegue a Roma: "Ademais constato que eles são comunicados a um pequeno número. Pois a comunicação ainda não era fácil, ela não se fazia de boa fé, nem simplesmente, mas selecionando-se com rigor aqueles que a recebiam".

Quer o texto transmitido por Eustóquio tenha sido uma verdadeira edição ou uma simples recensão, diferente do texto das Enéadas, é necessário com efeito admitir que as duas versões, a de Eustóquio e a das Enéadas, circularam paralelamente pois era possivel compará-las, como atesta o escólio.

Resta interrogarmo-nos sobre a fonte imediata das citações de Eusébio. Dois argumentos foram aventados para ligar as citações de Eusébio a uma versão pré-porfiriana do texto de Plotino: a divisão do tratado IV 7, cuja Preparação evangélica parece testemunhar e que está ausente das Enéadas (2), e a presença em Eusébio de um longo trecho ausente da edição porfiriana (3).

\section{0 texto de Eusébio testemunha uma divisão em dois livros do tratado IV 7 de Plotino?}

Eusébio cita extratos do tratado IV 7, Пع@i

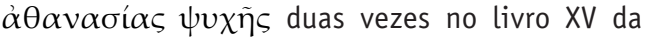
sua Preparação evangélica. Em XV 10, ele retoma o capítulo IV $7,8^{5}$, consagrado à enteléquia, e dá

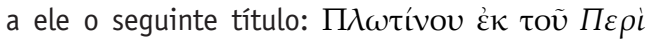

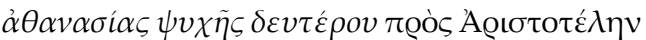

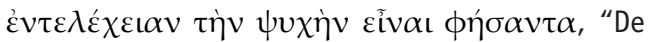
Plotino, tirado do segundo livro Sobre a imortalidade da alma, contra Aristóteles que pretendeu que a alma fosse uma enteléquia", e em XV 22 ele cita os capítulos IV 7, 1-8 ${ }^{4} .28$ com o título seguinte: Пoò

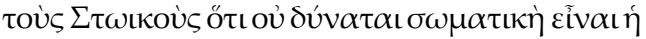

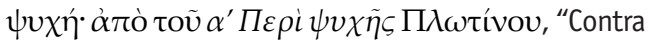
os Estóicos, que a alma não pode ser corporal; tirado do primeiro livro Sobre a alma".

Ainda que uma parte desses textos esteja ausente das Enéadas e independentemente do fato que Eusébio relacione os dois tratados a um título

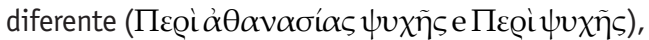
não há dúvida de que essas citações se relacionam

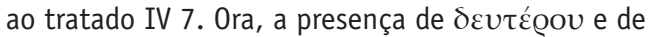
$\alpha^{\prime}$ sugere à primeira vista que no exemplar do qual Eusébio dispunha o tratado IV 7 estava dividido em dois tratados. É uma observação que P. Henry, J. Rist e W. Theiler aproveitaram bem.

P. Henry ${ }^{9}$, partindo do fato de que o escólio a IV 4, examinado acima, nos informa, sobre os tratados IV 3, 4 e 5, que a divisão dos tratados podia ser diferente em Eustóquio e em Porfírio, vê na divisão de IV 7 uma prova da proveniência eustóquiana das citações de Eusébio. Sendo as Enéadas agrupadas em seis séries de nove, se IV 7 fosse dividido em 2, elas contariam 55 tratados e não 54. Ele conclui disso que Eusébio não pode ter tirado seus extratos da edição porfiriana.

Henry e Schwyzer, no prefácio à sua Editio maior t. II, 1959, p. x, continuam a vislumbrar ao menos a possibilidade de que a divisão em dois livros que encontramos em Eusébio estivesse na edição de Eustóquio, porquanto se exprimem assim a propósito dos dois fragmentos presentes em Eusébio: “Non igitur errabimus, si Eusebium ex editione hausisse profitebimur, ubi in duos libros divisus erat idem 
textus. Quam fuisse Eustochii non prorsus constat, sed, quia alia ignoratur editio, veri simillimum est" [Portanto não erraremos, se reconhecermos que Eusébio os tirou de uma edição em que o mesmo texto era dividido em dois livros. Não é certo que tenha sido a de Eustóquio, mas, como se ignora uma outra edição, é muito verossímil].

J. Rist ${ }^{10}$, apoiando-se sobre a menção a um primeiro e a um segundo livro, acredita, também ele, que Eusébio conhecia uma edição de Plotino diferente daquela de Porfírio, na qual IV 7 estava dividido em dois, e que os extratos de Plotino que lemos na Preparação evangélica não provêm das Enéadas. Ele sublinha, aliás, que nada em Eusébio prova que este conhecesse mais tratados de Plotino além daqueles dois que ele cita: IV 7 e V 1. Preferentemente a uma edição de Eustóquio, ele pensa que os extratos citados por Eusébio poderiam vir dos exemplares de Amélio ou das cópias que Longino mandou fazer ${ }^{11}$.

W. Theiler ${ }^{12}$ recusa, por sua vez, que as citações de Eusébio pudessem vir de Eustóquio, e considera que a divisão de IV 7 em dois tratados que se encontra em Eusébio possa ser o vestígio de uma organização dos tratados plotinianos concebida inicialmente por Porfírio, e depois abandonada no momento da edição definitiva das Enéadas. Theiler parte do fato, já observado por Henry ${ }^{13}$, de que todos os manuscritos das Enéadas transmitem o escrito que nas edições é o tratado IV 1: Пع@i oủoí $\alpha \varsigma \psi v \chi \tilde{\eta} \varsigma$

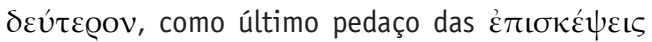

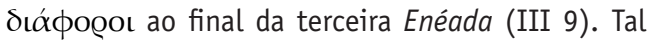
era, então, o lugar que Porfírio queria inicialmente atribuir a essa passagem em sua edição. Por outro lado, para obter o número de nove tratados na sua quarta Enéada, Porfírio teria previsto dividir em dois IV 7. Mas no último minuto, no momento em que ele escrevia a Vita Plotini, ele teria projetado colocar o último capítulo de III 9 depois do primeiro tratado da quarta Enéada (tendo Ficino o colocado equivocadamente em IV 1 no lugar de IV 2, as edições ulteriores conservaram-lhe esse número IV 1). A divisão de IV 7 tornava-se desde então inútil e Porfírio teria renunciado a ela. Mas no exemplar original do texto das Enéadas, essa modificação, que consistia em colocar o último capítulo de III 9 em segunda posição na quarta Enéada, só foi introduzida no último momento. Assim, todos os manuscritos teriam deixado IV 1 na sua antiga posição, isto é, no final de III 9 (ainda que disponhamos de duas versões do mesmo texto, uma no final de III 9 e outra em IV 1, com algumas variantes de uma para a outra) e que Eusébio, no exemplar que lia, via ainda o tratado IV 7 dividido em dois. Conforme essa hipótese, a divisão de IV 7 em Eusébio corresponderia então a uma etapa anterior à escolha final de Porfírio. Essas considerações de Theiler, na medida em que supõem que Eusébio utilizava um exemplar em que IV 7 era ainda dividido em dois conforme o que teria desejado Porfírio em um dado momento, vão no sentido de uma utilização por Eusébio das Enéadas, ou ao menos de uma versão preparatória destas, e não de um uso da edição de Eustóquio. Esse uso das Enéadas é tão mais verossímil, lembra ainda Theiler, que Eusébio na sua Preparação evangélica tinha o hábito de citar freqüentemente as obras de Porfírio.

Todavia, outros se recusaram a admitir que 0 tratado IV 7 tenha alguma vez sido objeto de uma divisão. É o caso, notadamente, de P. Kraus e de A. Carriker.

P. Kraus ${ }^{14}$, constatando que a primeira passagem citada por Eusébio em XV 10 na Eneáda IV 7 vem após a segunda passagem citada em XV 22, supõe que um leitor antigo da obra de Eusébio, comparando o texto deste último e o de Porfírio, pôde acrescentar em Eusébio, na margem desses dois extratos, as palavras $\delta \varepsilon v ́ \tau \varepsilon \varrho o v$ e $\pi \varrho \tilde{\omega} \tau o v, ~ a$ fim de indicar através disso a ordem original destes dois extratos no tratado de Plotino. Ele supõe ainda que na seqüência um copista integrou essas glosas em um texto que, persuadido de que se tratava de uma indicação de livros, ele corrigiu os nominativos em genitivos. Kraus observa, além disso, com razão, que uma separação do tratado em dois livros em $8^{5}$, quer tenha sido atribuída a Eustóquio ou a qualquer outro, teria repousado sobre uma análise muito pouco hábil do texto. 0 bom senso foi, de fato, separar 1-8 (críticas por Plotino das posições dos adversários) e 9-15 (posição pessoal de Plotino). Como veremos mais à frente, Kraus é quem parece ter formulado a hipótese mais correta.
10. J. Rist, "Basil's 'Neoplatonism': its Background and Nature", em P. J. Fedwick, Basil of Caesarea: Christian, Humanist, Ascetic. A SixteenHundredth Anniversary Symposium Pontifical Institute of Medieval Studies, Toronto, 1981, p 137-220, reproduzido em J. M. Rist, Platonism and its Christian Heritage, Variorum, London, 1985 étude $n^{0}$ XII (paginação idêntica) notadamente p. 140-41; 159-65.

11. Voltaremos adiante à posição de Rist.

12. Em sua resenha de P. Henry, Les états du texte de Plotin (1938), publicado em Byzantinesche Zeitschrift 41 (1941), p. 169-76, notadamente p. 174.

13. Henry, États, p. 37-40.

14. P. Kraus, “Un fragment prétendu de la recension d'Eusochius des oeuvres de Plotin", Revue de l'histoire des religions 113 (1936), p. 207-18; reproduzido em Alchemie, Ketzerei, Apokryphen, Gesammelte Aufsätze hrsg. und eing. von Rémi Brague, Olms, Hildersheim - Zürich - New York 1994, p. 301-12. 
15. H.-R. Schwyzer, art. "Plotinos", RE XXI 1, 1951, col. 506-507.

16. Falamos dessa obra na terceira parte do presente estudo.

17. A. Carriker, The Library of Eusebius of Cesarea, Brill, Leiden, 2003 (Supplements to Vigiliae Christianae, 67), notadamente $p$. 108-12.

18. Ver o que diz, a propósito do processo de composição de tais compilações, T. Dorandi, Le stylet et la tablette. Dans le secret des auteurs antiques, Les Belles Lettres, Paris, 2000 (L'âne d'or), p. 44-50, que se apóia em Plínio, Velho, em Clemente de Alexandria, no papiro de Orígenes $P C$ air 88747, e no papiro de Filodemo PHerc 1021
H.-R Schwyzer ${ }^{15}$, em seu artigo "Plotinos" de 1951, fez observar em seguida - e de fato, esta observação vai contar a hipótese da edição de Eustóquio que ele próprio e Henry continuam vislumbrando como uma possibilidade no prefácio do tomo II da Editio maior de 1959 - que não há traço algum de uma divisão de IV 7 no livro III da Pseudo-Teologia de Aristóteles ${ }^{16}$ no lugar onde se passa para o capítulo sobre a enteléquia.

Recentemente A. Carriker ${ }^{17}$ propôs uma nova explicação. Em XV 10, Eusébio pode ter remetido

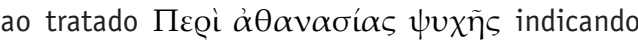

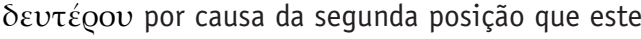
tratado ocupa na ordem cronológica dos tratados de Plotino, tal como nos foi transmitida pela Vita Plotini 4. 24. Carriker supõe, com efeito, que Eusébio tinha à sua disposição as Enéadas e também a Vita Plotini que lhes servia de introdução e na qual a ordem cronológica de composição dos tratados era indicada. Quando, em seguida, em XV 22, Eusébio cita novamente um extrato de IV 7, ele o designa como sendo o primeiro: á assinalando assim que o tratado Sobre a imortalidade da alma é o primeiro tratado consagrado ao tema da alma na ordem cronológica. Nos dois casos, Eusébio teria querido ajudar seu leitor, que ele supõe mais familiarizado com uma edição cronológica dos trados de Plotino - a de Amélio ou a de Eustóquio - do que com as Enéadas. 0 próprio Eusébio teria conhecido certos tratados através de uma dessas edições préporfirianas. Esta interpretação em si engenhosa apresenta fraquezas. Ela supõe que Eusébio tinha em mãos duas versões dos tratados plotinianos, uma versão pré-porfiriana e as Enéadas; que a ordem cronológica teria sido mais bem conhecida por seus leitores eventuais que a ordem das Enéadas; que Eusébio teria pensado ser útil ao seu leitor, ao fornecer a ele números sem qualquer explicação; enfim e sobretudo, que estes dois números não significam a mesma coisa, um indicando que o tratado é o segundo na ordem cronológica, e o outro, que se trata do primeiro tratado consagrado à alma. Esses elementos tornam a suposição de Carriker gratuita; nada atesta que os leitores de Eusébio possam ter conhecido duas edições do texto de Plotino.
Da nossa parte, é da explicação de Kraus que mais nos aproximamos. Mas é ao próprio Eusébio, mais do que a um leitor, que atribuiríamos a origem

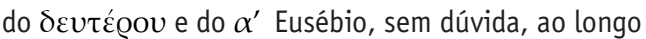
de suas leituras preparatórias ao livro XV da $P$. $E$., selecionou duas passagens de IV 7 que correspondem às duas temáticas que o interessavam (crítica dos Estóicos, depois crítica de Aristóteles com o capítulo sobre a enteléquia). Querendo a seguir dar ao seu copista instruções para a inserção dessas duas passagens no texto da Preparação evangélica, uma em XV 10 e outra em XV 22, ele pode, no esboço preparatório da obra em que devia precisar a lista de passagens a inserir e as transições ${ }^{18}$, ter indicado â' na seqüencia da referência do tratado de Plotino que ele desejava inserir em XV 10, para indicar ao copista que era o segundo extrato na ordem de IV 7 que deveria ser inserido em primeiro lugar. $A$ menção $\beta^{\prime}$ teria sido a seguir recopiada erroneamente pelo copista, que teria visto ali uma indicação de livro e que o teria juntado

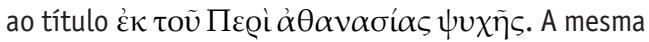
explicação pode ser dada da fórmula que está no título

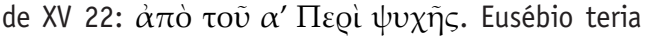
desejado indicar para seu copista que a passagem a inserir em XV 22 era o primeiro extrato na seqüência dos extratos de IV 7 que ele havia preparado.

Vários elementos apóiam essa hipótese. Primeiro, interpretar essas cifras como correspondendo ao número dos livros citados iria, no caso de

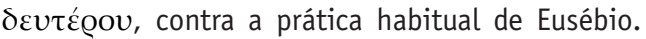
Uma referência como a do título de XV 10 (દ่ $\kappa$

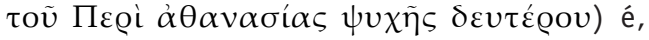
efetivamente, sem paralelo na obra. Eusébio em sua $P$. E., quer se trate do índice dos diferentes capítulos, dos títulos destes capítulos, ou dos títulos citados no texto como tal, não indica nunca o número de um livro após o título desse livro. Eis aqui exemplos de diferentes tipos de títulos com o número ordinal que encontramos na Preparação evangélica:

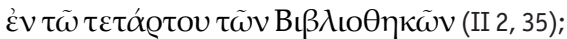

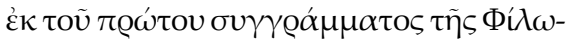

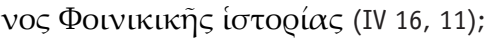

$\dot{\varepsilon} \nu \tau \tilde{\eta} \tau \varepsilon \tau \alpha \dot{\alpha} \varrho \tau \eta ~ ' I \tau \alpha \lambda \iota \kappa \tilde{\omega} \nu(I V 16,12) ;$

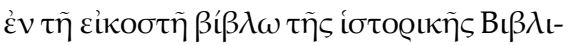

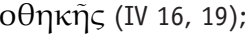




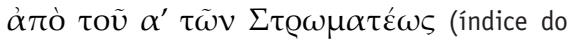
livro IX, título 6);

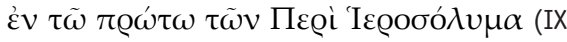
20, 1);

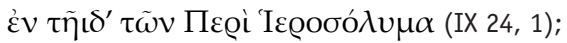

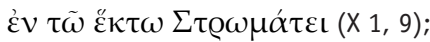

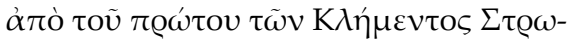
$\mu \alpha \tau \varepsilon \dot{c} \omega \nu$ (título de $X 12$ );

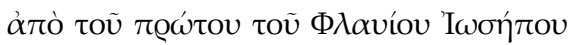

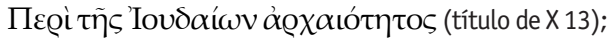

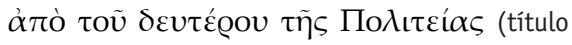
de XII 4);

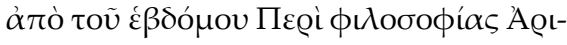
$\sigma \tau$ $\kappa \lambda$ ćouৎò (título de XV 14).

0 único (falso) caso que encontramos em que o ordinal tem o ar de ter sido colocado após o título se encontra em XI 9, 8; de fato, o ordinal é

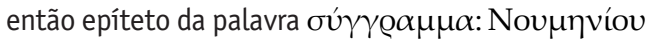

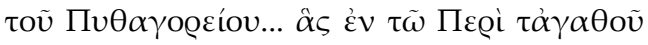

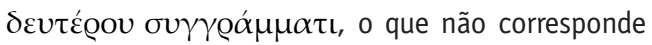
à fórmula empregada em XV 10.

Entretanto, reparamos, certamente não no texto, desta vez, mas no aparato, um outro caso

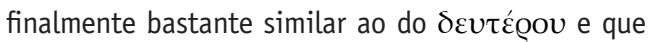
nos encoraja na nossa interpretação. Se olhamos 0 aparato de Mras, percebemos que em XV 2, enquanto B, um manuscrito da família 2, tem por título Пعœi

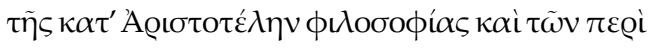

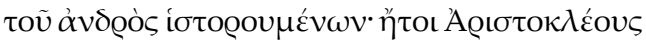

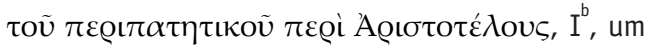
manuscrito da família 1, apresenta um título diferente com uma cifra ordinal colocada após o título:

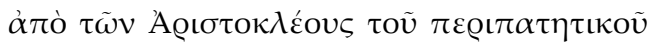

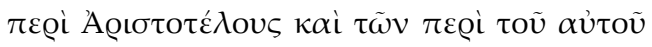

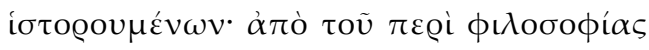
$\varepsilon \beta \delta o ́ \mu o v$, enquanto que outros três manuscritos da família 2, OVN, têm por título uma abreviação deste

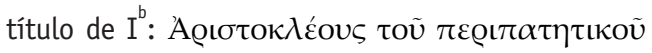
$\pi \varepsilon \varrho i$ Ạı prólogo do livro XV, Eusébio diz que vai expor a defesa de Aristóteles que Arístocles produziu, $\dot{\varepsilon} v \tau \tilde{\omega} \varepsilon \dot{\varepsilon} \beta \delta$ -

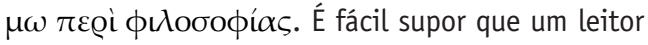
ou um copista acrescentou na margem do título do

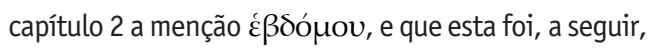
erroneamente incorporada ao título por um copista.
Este último, com efeito, não respeitou o modo de fazer habitual de Eusébio, e juntou o ordinal após o título. É divertido ver como os editores reagiram. Mras, dandose conta provavelmente de que Eusébio não teria formulado assim seu título, trocou o lugar do ordinal

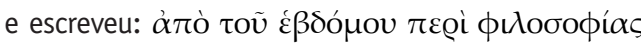

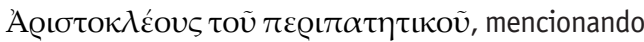
no aparato sua correção; des Places, tendo talvez observado a mesma coisa, preferiu escolher o título de

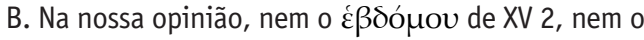

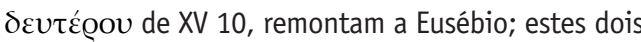
ordinais poderiam resultar de uma inserção ulterior devida, no caso de XV 2, a um cuidado de precisão de um copista ou de um leitor, e, no caso de XV 10, a uma má interpretação do copista.

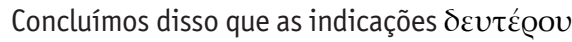
e $\alpha^{\prime}$ dadas por Eusébio no esboço preparatório da sua obra teriam sido mal interpretadas pelo copista, que as teria compreendido como indicações de livros e que, no lugar de suprimi-las, as teria juntado aos

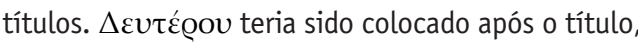
contrariamente ao modo de fazer habitual de Eusébio, enquanto que a introdução de $\alpha^{\prime}$ teria respeitado a prática deste ${ }^{19}$. De fato, como veremos um pouco mais à frente, não é verossimilmente $\delta \varepsilon v \tau \varepsilon ́$ @ov que Eusébio teria escrito, mas somente $\beta^{\prime}$, o que deixaria ao copista a interpretação do caso deste ordinal (nominativo, genitivo...).

Convém assinalar ainda que a tradição manuscrita de Eusébio, contrariamente ao que poderíamos crer consultando apenas a edição Mras e seu aparato, não é unânime no que concerne à indicação $\alpha^{\prime}$. Certos manuscritos, com efeito, não possuem esse $\alpha^{\prime}$. Talvez seja necessário ver aí um sinal de que essa indicação não era evidente; é difícil tirar conclusões mais precisas, pois não se pode excluir a negligência dos copistas que podem muito bem ter omitido um $\alpha^{\prime}$. É consultando as primeiras edições da P. E.: a de Robert Estienne (Paris, 1544), a de François Viguier (Paris, 1628) e a reimpressão desta última com tradução latina (Leipzig, 1688), que suspeitamos dessa falta de unanimidade. Ocorre, com efeito, que estas três edições, em seus índices e no título do segundo extrato, trazem ảंò

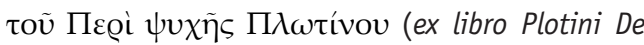
animo) sem nenhuma menção ao $\alpha^{\prime}$. As edições
19. Encontra-se em outros lugares, efetivamente, esse gênero de título em Eusébio. Assim, por exemplo, em XV 17:

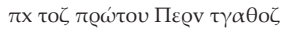
Noupqvíov, ou ainda, em XI 35 , 6: $v \tau \phi \varsigma \pi \varrho \omega ́ \tau \omega \varsigma ~ \Pi \varepsilon \varrho v ~ \psi v \chi Z \varsigma$. 
Estienne e Viguier se apoiaram em D (família 2) e E (família l), ao qual Viguier acrescentou lições de C (família 2). Algumas investigações sobre tradição manuscrita se nos impunham, conseqüentemente, a fim de compreendermos por que essas edições não comportavam o á. Uma brevíssima lembrança da situação da tradição manuscrita da Preparação evangélica pode ser útil.

20. Eusebius Werke, 8. Bd., Die Praeparatio euangelica, herausgegeben (...) Von K. Mras, 1. Teil, Akademie-Verlag, Berlin, 1954; 2. Teil, Berlin, 1956.

21. Cf. Mras, Eusebius Werke, I p. xiii-li.

22. Referir-se também ao trabalho anterior de P. Henry, em Recherches, p. 27-56 (ch. II: “Le témoignage des manuscrits").

23. Mras, Eusebius Werke, I, p. xlvi-xlvii, coloca D entre parênteses, pois considera que não o deve utilizar senão a título subsidiário ao lado de $\mathrm{N}$, uma vez que $N$ e $D$ são copiados sobre um mesmo modelo e que $D$, na totalidade, é de pior qualidade que $\mathrm{N}$.

24. Todos nossos agradecimentos vão aos colegas da seção grega do IRHT (Paris), que puseram à nossa disposição microfilmes e um CD-Rom da Preparação evangélica de Eusébio, graças aos quais nós pudemos fazer um bom número de verificações. e não possuem portanto o livro XV].
Lista dos manuscritos

Ainda que Mras, editor de referência ${ }^{20}$, não forneça um stemma como tal, ele explica na introdução do tomo I da sua edição de $1954^{21}$, que há duas grandes famílias de manuscritos da $P$. $E^{22}$. Nós pudemos consultar os representantes mais importantes delas:

\section{Família 1}

\section{A Parisinus graecus 451, escrito em 914;}

Copiado sobre A: $\mathrm{H}=$ Marcianus graecus 343, $X I^{0}$ S.;

[Nem A nem $\mathrm{H}$ nos interessarão, pois eles oferecem apenas os cinco primeiros livros da $P$. $E$.

I Marcianus graecus $341, X^{\circ}$ s. (este manuscrito I é escrito por uma primeira mão $I^{\mathrm{a}}$ até o fol. $265^{v}$ e do fol. 295 ao fol. 300 , depois por uma segunda mão I do fol. 266 ao fol. 294, as duas mãos tendo tido aparentemente o mesmo modelo);

Copiado sobre I: $\mathrm{j}$ = Marcianus graecus 342;

Copiado sobre j: $\mathrm{E}=$ Parisinus graecus 468, completado e corrigido a partir de D (família 2);

\section{Família 2}

0 Bononiensis graecus 3643, final do XIII ${ }^{\circ}$ S.;

Copiado sobre 0: G = Laurentianus VI 9, datado de 1344;

Copiado sobre G: $\mathrm{F}=$ Laurentianus VI 6, e C $=$ Parisinus graecus 466;

B Parisinus graecus 465, XIII ${ }^{\circ}$ s. (pertence à segunda família tendo ao mesmo tempo sido influenciado pela primeira);

$\mathrm{N}$ Neapolitanus graecus II AA 16 , do $\mathrm{XV}^{\circ}$ s.;

D Parisinus graecus 467, do XVI ${ }^{\circ}$ s.; copiado sobre o mesmo modelo que $\mathrm{N}$, exceto pelo livro IX, copiado sobre I ou sobre $j$;
V Vatopedinus 180, início do $\mathrm{XIV}^{0} \mathrm{~s}$. Aparatos da edição Mras

Vejamos agora as informações que nos fornece o aparato de Mras a propósito dos títulos de XV 10 e XV 22 da Preparação evangélica.

XV 10

No índice do livro XV (t. II, p 340) transmitido

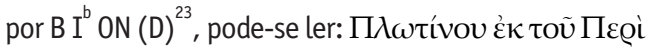

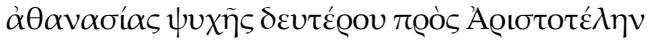

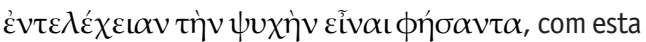
precisão no aparato crítico de que o título inteiro foi riscado em $\mathrm{B}$ no momento do trabalho de rubricatio.

No cabeçalho do capítulo XV 10, o título é idêntico ao do índice e podemos ler no aparato (t. II, p. 372): “Die Überschrift in I $\mathrm{b}^{\mathrm{b}} \mathrm{ONV}$ " com a precisão

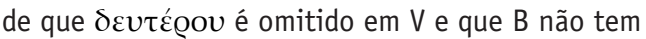
nem o título nem o capítulo.

\section{22}

No índice do livro XV (t. II, p. 340), o título

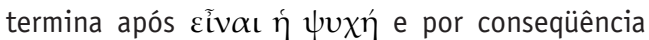
não oferece a precisão que nos interessa: Пழò

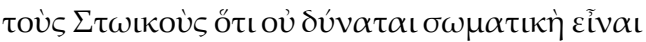

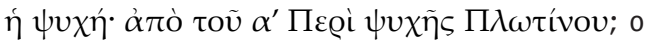
aparato precisa que em $B$ o título foi riscado no momento do trabalho de rubricatio.

No cabeçalho do capítulo XV 22, o título é mais completo que no índice: Пoòs toù $\Sigma \tau \omega$ เкoù

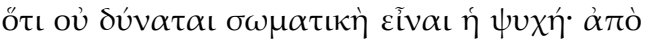

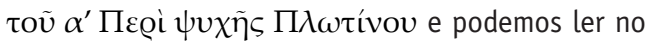
aparato (t. II, p. 387): “Die Überschrift in ONV" com a precisão de que $\alpha \dot{\alpha}$ ò $-\psi v \chi \tilde{\eta} \varsigma$ é omitido em $\mathrm{V}$ e que tanto o título como a maior parte do capítulo estão ausentes em B.

Pudemos consultar diretamente os manuscritos que se encontram na Bibliothèque nationale de France nas ocorrências $B, C, D, E$, e em microfilmes ou CD-Rom I, 0 e $\mathrm{N}^{24}$. Concernindo a XV 10, preferimos, por cuidado de maior clareza, dar as

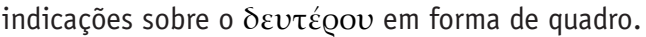

Constatamos que toda a tradição, exceto V, ao que parece, comporta o número ordinal, mais

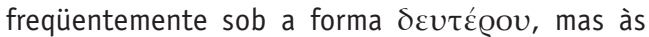

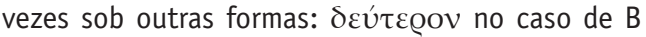




\begin{tabular}{|c|c|c|}
\hline Siglas dos manuscritos & Índice & Título no cabeçalho do capítulo \\
\hline I & fol. $280^{\mathrm{r}} \delta \varepsilon \cup \tau \dot{\varepsilon} \rho \circ v$ & fol. $291^{\mathrm{r}} \delta \varepsilon v \tau \varepsilon^{\prime} \rho$ ov \\
\hline $\mathrm{E}$ & fol. $413^{\mathrm{v}} \delta \varepsilon \cup \tau \dot{\varepsilon} \rho$ o v & fol. $413^{\mathrm{r}} \delta \varepsilon v \tau \varepsilon \dot{\varepsilon} \rho$ o \\
\hline B & fol. $189^{r} \Delta \varepsilon$ th & fol. $196^{\mathrm{r}}$ título + capítulo são omitidos \\
\hline $\mathrm{C}$ & fol. $333^{\mathrm{r}} \overline{\boldsymbol{b}}$ & 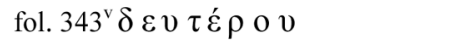 \\
\hline $\mathrm{D}$ & fol. $356^{\mathrm{r}} \overline{\boldsymbol{b}}$ & fol. $367^{\vee} \delta \varepsilon v \tau \varepsilon \dot{\varepsilon} \rho$ o v \\
\hline $\mathrm{O}$ & fol. $226^{\mathrm{r}} \boldsymbol{b}^{\alpha \varsigma}$ & fol. $233^{\mathrm{v}} \delta \varepsilon v \tau \varepsilon \varepsilon^{\prime} \rho$ o \\
\hline $\mathrm{N}$ & fol. $373^{v} \bar{B}$ & fol. $383^{\mathrm{v}} \delta \varepsilon v \tau \varepsilon \dot{\varepsilon} \rho$ o v \\
\hline V de acordo com o aparato de Mras & índice não consultado & 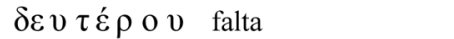 \\
\hline
\end{tabular}

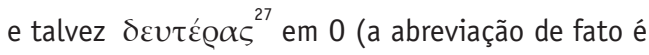
difícil de ler; podemos em todo caso dizer de modo

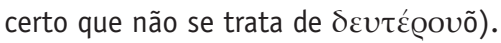

Notemos, ademais, uma divergência entre certos manuscritos, que traduz um problema suplementar e que a edição de Mras estranhamente não assinala. Em quatro manuscritos da família 2 ( $B, C, D$ e 0$)$, o índice,

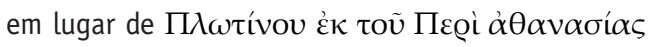
$\psi v \chi \tilde{\eta} \varsigma . .$. que lemos em outros manuscritos, oferece

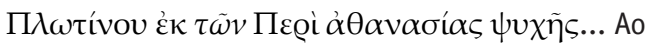
contrário, quando passamos ao título que precede 0 texto de XV 22, encontramos em C (fol. 343 $3^{\mathrm{v}}$ ), D (fol.

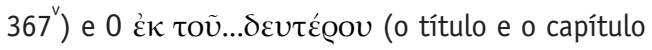
estão ausentes de B). Todos esses detalhes encorajam nossa hipótese. 0 título original podia se apresentar

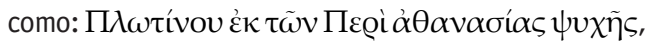
com um $\beta^{\prime}$ acrescido na margem, correspondendo à indicação dada por Eusébio. Um copista terá inserido no título esse $\beta^{\prime}$, que suscitou o embaraço quando se quis transcrevê-lo com letras, pois nada permitia adivinhar em qual caso convinha pô-lo, donde as hesitações que encontramos entre as formas

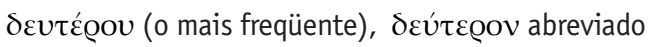

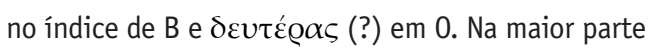
dos casos, como não se compreendia bem o que podia significar $\dot{\varepsilon} \kappa \tau \tilde{\omega} \nu . . . \beta^{\prime}$, supôs-se que se tratava de um número de livro e, por meio da correção de $\tau \tilde{\omega} v$ em

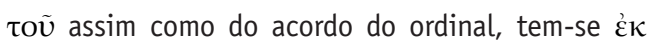

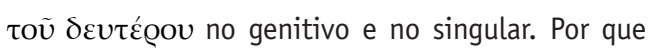
estimar que originalmente havia $\tau \tilde{\omega} \nu$ de preferência a $\tau o \tilde{v}$ ? Porque pode-se conceber que o $\tau \tilde{\omega} v$ tenha sido mudado em toṽ por causa da inserção do â', ao passo que o inverso não se explicaria.

Conforme essa hipótese, resta justificar a

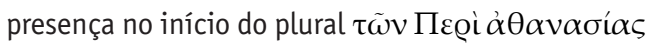
$\psi v \chi \tilde{\eta} \varsigma$, à primeira vista surpreendente, se houvesse apenas um livro nesse tratado e não dois. Com efeito, um tratado que não é dividido em vários livros pode ser citado com o artigo no plural; é necessário então subentender não $\beta \iota \beta \lambda i ́ \omega v$, mas $\lambda o ́ \gamma \omega v$. Assim, podem-se citar vários exemplos de títulos encontrados na Preparação evangélica ou em Diógenes Laércio, dos quais não se tem razão de pensar que comportavam mais de um livro, ou ao menos para os quais, em todo caso, a tradição não atesta a existência de vários livros: Eusébio, por

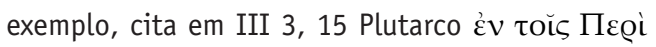

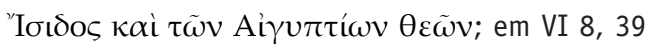

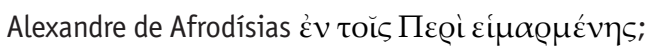

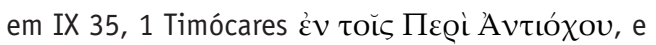

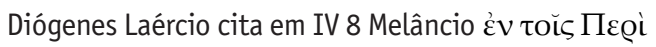
$\zeta \omega \gamma \varrho \alpha \phi \iota \kappa \tilde{\varsigma} \varsigma$, em I 112 e V 3 Demétrio Magnes

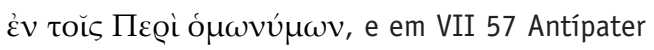

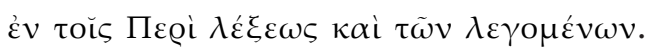
Essas observações sobre XV 10 convidam a concluir

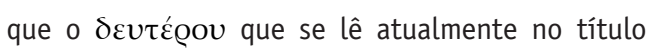
provavelmente não foi posto por Eusébio.

Vejamos agora o que ocorre em XV 22. No seu aparato, Mras não levou em conta a família l, dado que $A$ tem apenas os cinco primeiros capítulos da $P . E$. e que I no índice não tem a parte do título que comporta o $\alpha^{\prime}$ - pois ele omite $\alpha \dot{\alpha}$ ò... $\psi v \chi \tilde{\eta} \varsigma$ - , e que não tem o título no cabeçalho do capítulo, nem o capítulo. Não obstante, na falta de ser representado por A e I, a família l pode sê-lo pelo manuscrito de Paris $E$, copiado sobre $j$, ele próprio copiado sobre I, o manuscrito-fonte. Ora, em E no fol. 431v lê-se:

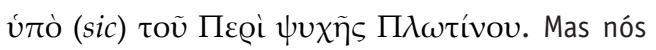
sabemos, por outro lado - é o que diz Mras na sua introdução $^{28}$ - que E foi completado e corrigido por D. Nós concluímos disso que a família I podia não ter $\alpha^{\prime}$ (seria necessário, para estar-se seguro disso,
25. Com efeito, no fol. $196 r$, no fim de XV 9, a dois terços da página, sem sinal algum de ruptura aparente, Eusébio escreve

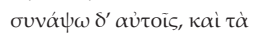

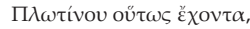
depois salta XV 10 (Plotino) e XV 11 (Porfírio) - capítulos que, efetivamente, foram riscados de vermelho no índice - para encadear diretamente com o título de XV 12.

26. Não pudemos consultar o manuscrito Vatopedinus 180. De sua parte, Mras explica (I, p. xlviii) que teve à sua disposição a reprodução fotográfica de um certo número de seus fólios, notadamente dos que contêm o livro XV em sua totalidade, mas não o índice: “Fol. 352v bis Fol. 352r: das ganze 15 . Buch (mit Ausnahme des Inhaltsverzeichnisses)".

27. Um copista, trabalhando de maneira um pouco mecânica, pode ter se deixado levar pela presença de $\psi v \times \tilde{\eta} \varsigma$ e colocado o adjetivo no genitivo feminino singular.

28. Mras, Eusebius Werke, I, p. xxxiii. 
fazer uma verificação em $\mathrm{j}$ ), ou que $\mathrm{E}$ foi influenciado por $\mathrm{D}$, que pertence à família 2 .

Dispomos de testemunhos mais numerosos concernentes à família 2. Em todos os manuscritos que consultamos ${ }^{29}$, o índice omite $\dot{\alpha} \pi$ ò... $\psi v \chi \tilde{\eta} \varsigma$.

29. Em B, o título do índice, que também apresenta essa omissão, está riscado em vermelho pelo rubricador. Quanto a V, Mras não pôde consultar o ou os fólios que comportavam o índice.

30. No fol. $199 \mathrm{v}$, o fim do cap.

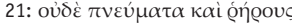

(sic, em lugar de $\lambda$ ńøous) se encadeia diretamente com XV 22

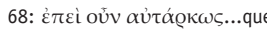
constitui o começo da transição entre XV 22 e 23.

31. Enquanto em sua Editio maior Henry e Schwyzer indicam claramente que 0 e $\mathrm{N}$ têm ambos 0 $\alpha^{\prime}$ e que $D$ o omite, no aparato da minor (t. II, p. 137) dá a entender que OND comporta o $\alpha^{\prime}$ o que falso no caso de $D$.

32. Mras, Eusebius Werke, I, p. liv-lv.

33. Outras passagens da Teologia remetem às perícopes $\mathrm{A}$ e $\mathrm{D}$. Para não sobrecarregar o presente quadro, nós não as indicamos aqui; elas serão encontradas num outro quadro mais adiante. Conseqüentemente, ele não é de nenhuma ajuda para resolver o problema do $\alpha^{\prime}$. A respeito do título no cabeçalho do capítulo, ele está faltando, assim como a totalidade do texto de Plotino em $\mathrm{B}^{30}$. 0 manuscrito V, conforme o aparato de Mras, não comporta tampouco a parte $\alpha \dot{\alpha}$ ò... $\psi v \chi \tilde{\eta} \varsigma$; ele nos concerne pelo problema do á'. Restam, por conseqüência, quatro manuscritos da família 2: 0, C, N, D. Pudemos verificar que 0 (fol. 236 ${ }^{r}$ ), C (fol. 349 ${ }^{r}$ ) e N (fol. 386 ${ }^{r}$ ) comportam o á. Por outro lado, em D (fol. 373'), que é todavia um representante da família 2, lemos

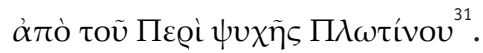

A conclusão dessas verificações laboriosas, mas necessárias, é que a família l, ao menos parcialmente (em E, em todo caso), não comportava o $\alpha^{\prime}$, enquanto a família 2 , à exceção de $D, 0$ comportava; compreendemos melhor então por que, nas edições Estienne e Viguier, que se apóiam sobre $D$ e $E$, o $\alpha^{\prime}$ está ausente.

No total o $\beta$ ' se manteve sob diferentes formas em toda a tradição, mas com os problemas por nós assinalados, que traduzem o embaraço dos copistas (e dos editores), enquanto o $\alpha^{\prime}$ não foi conservado em todos os lugares, talvez porque houvesse uma dúvida quanto à sua validade. Mantemos, portanto, nossa hipótese: as duas indicações, mesmo se se devessem a Eusébio, não faziam parte dos títulos que este havia redigido originalmente; é por acidente que elas terminaram por ser incorporadas aos títulos dos extratos; por conseqüência IV 7 jamais foi dividido em dois tratados e essa divisão não poderia ser aventada como prova da utilização de uma edição pré-porfiriana, qualquer que seja.

Pode-se então legitimamente se colocar uma questão subsidiaria. Por que Eusébio, se o tratado IV 7 não era dividido, teria dado dois títulos diferentes aos dois extratos do mesmo tratado IV 7, Пв@i

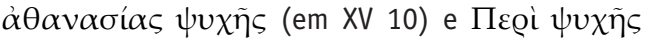
(em XV 22)? Duas respostas ao menos podem ser

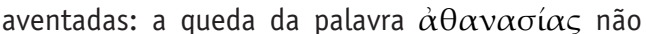
poderia ser excluída ou Eusébio, que já havia citado o titulo longo, bem pode, por cuidado de simplificação, ter-se contentado na segunda vez em indicar o tema principal do tratado.

\section{Da grande lacuna de IV 7 nas Enéadas pode-se concluir que Eusébio utilizava uma edição pré-porfiriana?}

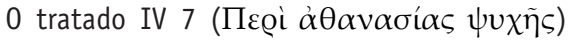
apresenta em todos os manuscritos das Enéadas uma grande lacuna a partir de IV 7, 8. 28 até $8^{5}$. 49. A existência dessa lacuna se manifesta com evidência por um encadeamento desprovido de sentido entre as

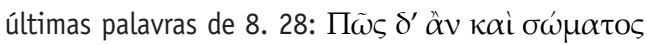

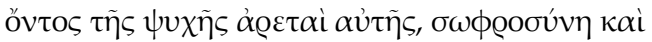

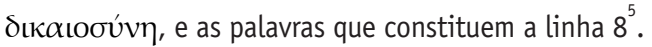

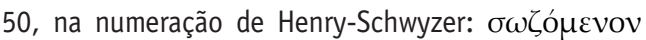

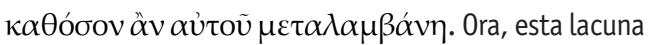
pode ser preenchida graças às duas passagens do livro XV da P.E. de Eusébio que acabamos de evocar, cuja redação se situa entre 312 e 322 (cf. Mras na introdução de sua edição da P.E. $)^{32}$. A presença de tal lacuna na tradição porfiriana não seria prova de que Eusébio teve acesso a uma outra edição que não a das Enéadas?

Eis o conjunto dos dados segundo a divisão em perícopes sugerida por Henry.

\begin{tabular}{|c|c|c|c|c|c|}
\hline Perícopes & IV 7 & Enéadas & Eusébio & $\begin{array}{l}E n . \\
\mathrm{J}, \mathrm{M}, \mathrm{V}\end{array}$ & $\begin{array}{l}\text { Teologia }{ }^{33} \text { III } \\
27-76\end{array}$ \\
\hline \multirow[t]{2}{*}{ A } & 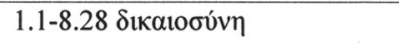 & + & & + & $\cdot$ \\
\hline & & & XV 22.1-67 & & \\
\hline B & $8.28-8^{4} .28$ à $\rho \mu o^{\prime} \alpha$ & 0 & & + & $8.38-8^{5} .20$ \\
\hline \multirow[t]{3}{*}{$\mathrm{C}$} & 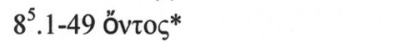 & 0 & & 0 & \\
\hline & & & XV 10.1-9 & & \\
\hline & $8^{5} .50 \sigma \omega \zeta o ́ \mu \varepsilon v o v . . . \mu \varepsilon \tau \alpha \lambda \alpha \mu \beta \alpha ́ v \eta ̣$ & + & & + & \\
\hline $\mathrm{D}$ & 9.1-15.12 á $\pi \mathrm{o} \lambda \omega \lambda \nu \tilde{\alpha} \alpha$ & + & & + & \\
\hline
\end{tabular}

* $8^{5}$.1-43: sobre a enteléquia 
Em XV 10, 1-9 (= a perícope $C$ na terminologia de Henry), Eusébio cita IV 7, $8^{5}$, uma passagem sobre a enteléquia que ele é o único a ter transmitido e que não acontece de nenhum manuscrito das Enéadas ter conservado.

Em XV 22, 1-67 Eusébio nos transmite sucessivamente:

- IV 7, 1-8. 28 que se lê nos manuscritos das Enéadas (= a perícope $\mathrm{A}$ );

- IV 7, 8. 28-8 $8^{4} .28$ ausente dos manuscritos das Enéadas (= a perícope $\mathrm{B})^{34}$. Onde os manuscritos

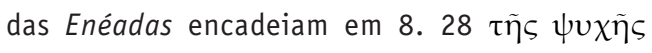

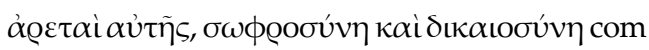

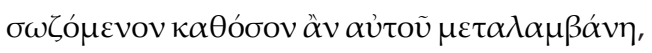
o que não apresenta nenhum sentido, Eusébio encadeia muito naturalmente com $\alpha \dot{v} \delta \varrho i ́ \alpha \tau \varepsilon \kappa \alpha i$ $\alpha i$ i $\alpha \varkappa \lambda \lambda \alpha$, o que é sua sequiência evidente. 0 texto de Eusébio de XV 22 termina com a conclusão oủk

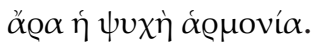

Seguindo Fr. Creuzer, no tomo III, col. 202 b da sua edição dos Plotini Opera (1835), P. Henry construiu toda uma teoria ${ }^{35}$ para mostrar, a partir da Preparação evangélica de Eusébio, que era necessário supor a existência de uma edição de Eustóquio que Eusébio teria utilizado. Como essa teoria teve muita influência e fez intervirem argumentos interessantes, nós a rememoramos rapidamente, ainda que ela seja pouco lembrada hoje.

0 argumento de P. Henry em favor das duas edições antigas diferentes dos textos de Plotino repousava sobre diversos elementos ${ }^{36}$. Inicialmente sobre o estudo do grande número de lições divergentes da perícope $A$, que é comum aos manuscritos das Enéadas e aos manuscritos de Eusébio $^{37}$. Ele encontrava, a seguir, confirmação de sua hipótese na análise da qualidade dessas variantes $^{38}$. Os "pretensos" erros de copistas, que se encontram no texto de Eusébio, objetivamente pior que o das Enéadas, seriam segundo ele erros de Plotino - de quem Porfírio na V. P. 8, 4-6 recorda que 0 estilo e a ortografia deixavam a desejar. As Enéadas, ao contrário, foram submetidas às correções de Porfírio, o que explicaria sua melhor qualidade. A edição da qual Eusébio se servia não seria, então, aquela das Enéadas publicada por Porfírio $^{39}$. Henry, ao menos no início, também tirava argumento do fato de que três manuscritos das Enéadas: J, $\mathrm{M}$ e $\mathrm{V}^{40}$, haviam conservado a perícope B. Em 1935, ele concluía que os copistas destes manuscritos podiam ter encontrado esta perícope na edição de Eustóquio ${ }^{41}$. Mas, desde 1941, ele nuançava esse ponto de vista, escrevendo: “A perícope [B] não provém de nenhum manuscrito conhecido de Eusébio, nem mesmo de seu arquétipo comum. Sem dúvida ela provém de um manuscrito da Preparação, mais do que diretamente de uma edição eustoquiana de Plotino, mas ele entrou na tradição porfiriana por intermédio de um manuscrito dessa tradição, chamada JCMV..." ${ }^{42}$, e, um pouco mais à frente ${ }^{43}$, ele insistia ainda no fato de que o manuscrito da Preparação não é nenhum dos manuscritos conhecidos, nem $T^{44}$ nem 0 nem $D$ nem $Q$, nem mesmo seu arquétipo comum. Mais tarde, em 1959, Henry e Schwyzer, no aparato da sua edição ${ }^{45}$, continuavam explicando a presença da perícope $B$ nesses três manuscritos por uma contaminação com a tradição de Eusébio: “Quae in JMV addita sunt, ex Eusebii quodam deperdito codice codicis $T$ affini supremam originem ducunt" [Os que foram ajuntados em JMV levam a uma origem suprema a partir de algum códice perdido de Eusébio afim ao códice $T$. Henry finalmente recorre, para explicar a presença da perícope $B$ nesses três manuscritos, a uma contaminação de um manuscrito das Enéadas, hoje perdido, por um manuscrito igualmente perdido da Preparação evangélica. Sem ter necessariamente renunciado à hipótese de uma edição de Eustóquio, ele dissocia desta hipótese a origem eusebiana da presença em JMV da perícope $B$.

Henry se apoiava igualmente na perícope $C$, isto é, o capítulo sobre a enteléquia conservado somente em Eusébio. Antes dele já Creuzer via neste pedaço um dos raros vestígios da edição de Eustóquio: Plotino teria escrito o capítulo sobre a enteléquia; Eustóquio o teria publicado em sua edição e é daí que Eusébio o teria tirado; Porfírio, ao contrário, não o teria mantido. A interpretação de Henry, um pouco diferente, encontra a de Creuzer na sua conclusão: “Quando ele redigiu seu tratado, Plotino evitou deliberadamente atacar a teoria da enteléquia, porém mais tarde, retomando a questão, ele fez Eustóquio inserir ali o fragmento que Eusébio
33. Outras passagens da Teologia remetem às perícopes $\mathrm{A}$ e $\mathrm{D}$. Para não sobrecarregar o presente quadro, nós não as indicamos aqui; elas serão encontradas num outro quadro mais adiante.

34. É preciso assinalar, contudo, que os três manuscritos das Enéadas: J (= Par. gr. 2082), M (= Marc. gr. 240) e V (= Vind. phil. gr. 226), conservaram a perícope B, a saber IV 7, 8.28-84.28 (0 manuscrito $V$, de fato, termina em 84.13 em razão provavelmente de um salto do mesmo ao mesmo sobre a palavra a(rmoni/a; sobre esse manuscrito, ver H.-R. Schwyzer, “Der Plotin-Codex Vindobonensis phil. graecus 226", Rheinisches Museum für Philologie 86 [1937], p. 270-85). Mas nós veremos mais adiante que é a partir da Preparação evangélica que esse ramo da tradição reparou a lacuna. Pode-se surpreender-se que os copistas desses manuscritos copiaram somente uma parte dessa lacuna e se omitiram de copiar 85 sobre a enteléquia! Deve-se, por outro lado, eliminar a possibilidade de que esses três manuscritos sejam os testemunhos de uma versão deteriorada da tradição direta das Enéadas, porque a linha de demarcação não é fortuita, mas corresponde a uma mudança de capítulo.

35. Henry, Recherches sur la Préparation evangélique d'Eusebe; ver também Henry e Schwyzer, Editio maior, t. II, p. ix-xvii.

36. Já assinalamos o escólio concernindo a Eustóquio e também à divisão de IV 7.

37. Henry, Recherches, p. 60-66. 38. Ibidem, p. 67-73.

39. Ibidem, p. 71.

40. Ver a nota 34.

41. Ver Henry, Recherches sur la Préparation evangélique d'Eusebe, p. 116.

42. P. Henry, Études plotiniennes, II, Les manuscrits des Ennéades, Desclée de Brouwer, ParisBruxelles, 1941, p. 235 (Museum Lessianum, section philosophique, 21).

43. Ibidem, p. 339.

44. Em “Das Plotin-Exzerpt im Codex Rossianus graecus 936", Rheinisches Museum für Philologie 88 (1939), p. 367-79, H.-R.

Schwyzer consagrou um estudo a $T$, levado em conta por Henry em Les manuscrits des Ennéades, mas Henry não admitia conclusão 
de Schwyzer, segundo a qual o pequeno número de variantes que oferece $T$ em relação ao texto das

Enéadas convida a pensar que Eusébio conhecia IV 7 na versão das Enéadas.

45. No t. II, p. 197

46. Henry, Recherches sur la Préparation evangélique d'Eusebe, p. 125-28.

47. No tomo II, p. ix-x

48. M. H. A. L. H. van der Valk, "A few observations on the text of Plotinus", Mnemosyne 9 (1956), p. 114-31, chega a uma conclusão outra que Henry a respeito dessas variantes. 0 estilo de Plotino é negligente, então os autores que o citam, quer se trate de Eusébio,

Teodoreto ou Cirilo, podiam facilmente fazer conscientemente ou inconscientemente alterações.

Seria então a Eusébio mesmo,

chocado pelo estilo relaxado

de Plotino, e não à edição de

Eustóquio, que deveriam ser

atribuídas as variantes de P.E.

Quanto a Dörrie, resenha do

tomo II da Editio maior de $\mathrm{H}-\mathrm{S}$,

Gnomon 36 (1964), p. 461-69,

notadamente p. 468-69, ele considera que as variantes do

texto de Eusébio são faltas que

não são produzidas antes de

Porfírio fazer sua edição, como o

queria Henry, mas depois, e que

elas se devem de fato aos copistas

do texto de Eusébio pouco

habituados ao estilo particula de Plotino.

49. Ver États, p. 7-105.

50. C. D'Ancona, “The Arabic version of Enn. 7 [2] and its Greek model", em J. E. Montgomery (ed.), Arabic Theology, Arabic Philosophy: From the Many to the One: Essays in Celebration of Richard M. Frank (Orientalia Lovaniensia Analecta), Leuven, Peeters Publishers, p. 127-56

51. H.-R. Schwyzer, “Das PlotinExzerpt im Codex Rossianus graecus 936", Rheinisches Museum für Philologie 88 (1939), p. 367-79.

52. P. Kraus, “Un fragment prétendu de la recension d'Eusochius des œuvres de Plotin", Revue de l'histoire des religions 113 (1936), p. 207-18

53. Ver a introdução da obra recém-publicada sob a direção de C. D’Ancona, Plotino. La discesa dell'anima nei corpi (Enn. IV 8

[6]). Plotiniana arabica (Pseudo Teologia di Aristotele, cita, a menos que tenha sido o próprio Eustóquio que o tenha inserido por sua própria conta...0 texto pode não ter se encontrado na edição de Porfírio; ou ainda: não podemos provar de modo decisivo que ele tenha feito parte dela. Seja como for, o certo é que nós o conhecemos somente sob a forma que ele tinha na edição de Eustóquio" ${ }^{46}$. Na Editio maior Henry e Schwyzer mantêm a possibilidade de uma proveniência eustoquiana $^{47}$.

Hoje, na realidade, nenhum dos argumentos aventados por Creuzer, depois por Henry, para provar que a P.E. de Eusébio está baseada na edição de Eustóquio, resiste. 0 argumento do número de variantes, produzido por Henry, é de ser manejado. Basta que Eusébio tenha recopiado os dois tratados de Plotino sobre um exemplar copiado por um escriba particularmente negligente para que as duas tradições das Enéadas e da P.E. se separem, cada uma conservando em todos seus manuscritos suas próprias variantes. Quanto ao argumento da qualidade dessas variantes, ele é tão difícil de ser manejado quanto o precedente. Conforme se pense que Eusébio dispunha de uma edição pré-porfiriana ou das Enéadas como tais, atribuem-se as ou a Plotino ou a Eusébio e a seus copistas ${ }^{48}$. Certo é que o texto da P.E. é globalmente melhor que o das Enéadas, como o mostram não somente as variantes da perícope A que fornece Henry ${ }^{49}$, mas também o número bastante importante de saltos do mesmo ao mesmo que podemos relevar na tradição de Eusébio (ex. em IV 7, 1. 6; 2. 4; 6. 47; 7. 1; 7. 18-20). Recentemente C. D'Ancona ${ }^{50}$ um balanço muito claro dessa questão das variantes em que, apoiando-se notadamente no artigo de Schwyzer consagrado a $T^{51}$, explica por que o estudo das variantes convida a pensar que Eusébio dispunha certamente da versão das Enéadas para as passagens de Plotino que ele cita, o que vem confirmar a tradução indireta representada pela versão árabe de IV 7, que contém ao mesmo tempo a perícope $B$ e uma parte da perícope $C$.

Resta o problema da perícope $C$ ausente da tradição das Enéadas. 0 estudo mais decisivo, que mostra que Henry está errado sobre esse ponto e que Eusébio conhecia os tratados de Plotino na versão das Enéadas é o de Kraus ${ }^{52}$. Este introduz a
Pseudo-Teologia de Aristóteles. Essa obra em língua árabe, que é datada de cerca de 840, retoma vários extratos de tratados plotinianos e se apresenta como sendo de Aristóteles ${ }^{53}$. Kraus prova que a obra se apóia na edição das Enéadas e que ela oferece um texto que remonta ao $\mathrm{VI}^{\circ}$ século, anterior portanto ao arquétipo da tradição manuscrita ${ }^{54}$. Kraus percebe que o nome de Porfírio é citado no título do primeiro capítulo da Pseudo-Teologia ${ }^{55}$, o que é igualmente um dado objetivo a não se negligenciar, e ele se apóia no conteúdo dessa obra para demonstrar que as Enéadas comportavam primitivamente as perícopes $B$ e $C$, que $P$. Henry queria atribuir à edição de Eustóquio. Acontece, com efeito, que a Pseudo-Teologia contém passagens paralelas a várias passagens de IV 7. De acordo com a Editio maior de Henry e Schwyzer, que cita face a face o texto grego de IV 7 e a tradução inglesa de G. Lewis das passagens correspondentes da Pseudo-Teologia de Aristóteles, notam-se as seguintes correspondências:

\begin{tabular}{lll}
\hline Teol. & En. & \\
\hline IX 1-63 & IV 7, 1-4.30 & $=$ A \\
III 27-33 & IV 7, 8.38-81.9 & $=$ B \\
III 1-6 & IV 7, $8^{1} .9-13$ & $=$ B \\
III 7-26 & IV 7, 8 $8^{1} .16-8^{2} .11$ & $=\mathrm{B}$ \\
III 34-76 & IV 7, 8 $.15-8^{5} .20$ & $=\mathrm{B}+\mathrm{C}$ \\
I 1-20 & IV 7, 13-15 & $=\mathrm{D}$ \\
\hline
\end{tabular}

A Pseudo-Teologia nos conservou, de fato, a primeira metade da perícope $A$, a maior parte da perícope $B$ (faltam apenas as 10 primeiras linhas) e o começo da C, por fim a parte final da perícope D. Assim, essa obra atesta a presença das quatro perícopes e prova que a perícope $C$ seguia diretamente a B. Kraus disso concluiu: “0 texto da Teologia confirma que é um bom caminho completar a lacuna dos manuscritos gregos através dos extratos de Eusébio" ${ }^{\prime 56}$. Seria, portanto, por uma corrupção mecânica, que sem dúvida não seria anterior ao VI ${ }^{\circ}$ século - a mesma que explica o desaparecimento da perícope $B$ - que se deveria explicar a ausência do texto sobre a enteléquia nos manuscritos das Enéadas. Essa precisão é capital. É possivel, por conseqüência, que Eusébio tenho tido em mãos 
uma edição das Enéadas que ainda comportasse as perícopes $B$ e $C$ hoje ausentes da tradição das Enéadas. A partir desse fato, não é de modo algum necessário recorrer, para explicar Eusébio, a uma edição pré-porfiriana das Enéadas, quer se pense nos exemplares de Amélio ou nos de Eustóquio.

Schwyzer, desde 1941, continuou a reflexão no mesmo sentido e provou que a Pseudo-Teologia de Aristóteles supõe a edição das Enéadas ${ }^{57}$. Eis quais são os argumentos que ele enunciou em seu artigo “Plotinos" ${ }^{158}$ :

- A Teologia não segue nem a ordem cronológica nem a ordem das Enéadas. Partes de um mesmo tratado podem se encontrar em lugares diferentes da Teologia. No entanto, graças à concordância que pode ser estabelecida entre as partes plotinianas que estão na base da Teologia (IV 3, IV 4, IV 7, IV 8, V 1, V 2, V 8 e VI 7) e as passagens correspondentes da Teologia, pode-se mostrar que a escolha operada na Teologia é impensável sem a edição das Enéadas. Aliás, o simples fato de que a Teologia se apóia em três Enéadas somente: IV, V e VI, supõe na realidade a divisão em Enéadas.

- IV 3 e IV 4, na origem, formavam um só tratado; é Porfírio quem o fez dois, caindo a cesura entre os dois bem no meio de uma frase. Ora, o segundo livro da Teologia começa com o início de IV 4; a conclusão de IV 3 não tem correspondente, 0 que é sinal de que a Teologia se baseia num exemplar dos tratados plotinianos que já comportava a cesura imposta por Porfírio.

- V 8 foi separado por Porfírio do conjunto III 8 [30], V 8 [31], V 5 [32], II 9 [33], que constituía o grande tratado antignóstico de Plotino ${ }^{59}$. Ora, na Teologia IV 1-59, X 137-194 e VIII 144-189 Lewis, 0 que corresponde a $V 8$ começa e termina sem que as ligações com III 8 e V 5 sejam indicadas, ao passo que podemos encontrar facilmente essas ligações ao lermos III 8, V 8 e V 5 em seqüência; a maior parte dos capítulos de V 8 é tomada em consideração, enquanto que não se trata de V 5 nem de III 8 nem de II 9, o que deveria ter sido o caso, se a Teologia se apoiasse num exemplar anterior às Enéadas.

- De uma divisão de IV atestada pelo menos em aparência por Eusébio (cf. o problema de

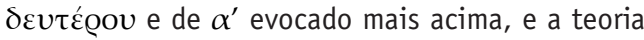
de P. Henry exposta precedentemente), não há traço algum no livro III da Teologia, que empresta numerosas passagens de IV 7.

Aos elementos assinalados por Schwyzer, pode-se acrescentar esta constatação de Theiler ${ }^{60}$ : na Teologia, IV (tratado 6 na ordem cronológica) segue IV 7 (tratado 2 na ordem cronológica), o que sugere aí também uma utilização da versão porfiriana dos escritos de Plotino.

Acessoriamente, o estudo de Schwyzer arruína definitivamente a tese de Henry ${ }^{61}$, que, de início, pensara que a Teologia se apoiava nos cem livros de Escólios que Amélio, durante sua estada em Roma, redigira a partir dos cursos de Plotino. Um dos argumentos de Henry era que não se encontra eco algum, na obra árabe, dos nove últimos tratados escritos por Plotino após partida de Amélio para a Apaméia ${ }^{62}$. Mas a ausência desses nove tratados na Teologia não prova que a Teologia depende dos Escólios de Amélio, na medida em que ocorre que apenas um desses nove tratados, a saber, V 3, pertence às três Enéadas que explora a Teologia.

A conclusão de Schwyzer é firme: “Diese Gründe...lassen es als unabweisbar erscheinen, dass die Enneaden dem Verfasser des griechischen Originals [scil. der Theologie] vorgelegen haben" ${ }^{\prime 63}$ [Esses motivos deixam transparecer que as Enéadas estavam presentes ao autor do original grego da Teologia]. Graças aos estudos de Kraus e de Schwyzer sobre a Pseudo-Teologia de Aristóteles, sabe-se que a tradição das Enéadas comportava a passagem sobre a enteléquia e que de fato, graças a Eusébio, pode-se reconstituir a grande lacuna das Enéadas provocada por um incidente mecânico e considerar que as perícopes $A, B, C$ e D formavam, de início, um único texto na edição porfiriana.

C. D'Ancona ${ }^{64}$ tira do magistral estudo de Schwyzer a conseqüência que se impõe: "All in all, what the Arabic gives us is a testimony of the Enneadic text antedating the archetype...one can use the Arabic version as an additional testimony in reconstructing, by comparison with Eusebius' quotation, what the original Enneadic text might have been in sections $B$ and $C^{\prime \prime}$ [Em resumo, o que
Capitoli 1 e 7; "Detti del Sapienti Greco", Il Poligrafo, Padova, 2003 (Subsidia Medievalia Patavina, 4), notadamente p. 72-91. Ver igualmente M. Aouad, nota a "A Teologia de Aristóteles e outros textos do Plotinus Arabus", Dictionnaire des Philosophes Antiques, publicado sob a direção de R. Goulet, I, Éd. du CNRS, Paris, 1989 , p. 541-90, notadamente p. 546

54. 0 arquétipo das Enéadas sem dúvida fazia parte da "Coleção filosófica", um conjunto de manuscritos copiados em Constantinopla na segunda metade do ES século. Ver a introdução de L. G. Westerink ao tomo I da edição Combès-Westerink do Tratado dos Princípios Primeiros de Damáscio, Paris, 1986 (Collection des Universités de France), p. Lxxiii-lxxx, bem como 0 artigo de R. Goulet, “La conservation et la transmission des textes philosophiques grecs", em C. D'Ancona (ed.), The Libraries of the Neoplatonists, Leiden-Boston, Brill, 2007 (Philosophia Antiqua, 107), p. 29-61, notadamente p. 54-58.

55. "Primeiro capítulo do livro de Aristóteles, o filósofo, chamado em grego Teologia, isto é, o discurso sobre a soberania divina. Comentário de Porfírio, o Tírio..." (trad. M. Aouad).

56. P. Kraus, “Un fragment prétendu de la recension d'Eusochius des oeuvres de Plotin", p. 214

57. H.-R. Schwyzer, “Die pseudoaristotelische Theologie und die Plotin-Ausgabe des Porphyrios", Reinisches Musem für Philologie 90 (1941), p. 216-36; depois, Id., art. "Plotinos", RE XX 1, 1951, col. 499-508; Nachtrag, RE Supp. XV, col. 319-21; Henry e Schwyzer, prefácio ao tomo II da Editio maior (1959), p. xxxi-xxxvi, e também P. Thillet, “Indices porphyriens dans la Théologie d'Aristote", em Le Néoplatonisme, Actes Du Colloque international du CNRS (Sciences humaines), Éd. du CNRS, Paris, 1971, p. 293-302.

58. Nas colunas 506-507.

59. R. Harder, "Eine neue Schrift Plotins", Hermes 71 (1936), p. 1-10, provou que esses quatro tratados formavam, na origem, apenas um e propôs uma explicação da divisão em quatro desse grande tratado presente já no quadro cronológico da Vita Plotini. Cf. nosso estudo “''arrière- 
plan scolaire de la Vie de Plotin", em Brisson et alii, Porphyre, La Vie de Plotin, I, p. 231-327 notadamente p. 301-303.

60. W. Theiler, resenha de Henry, Les États du text de Plotin, em Byzantinische Zeitschrift 41 (1941), p. 170

61. P. Henry, "Vers reconstituition de l'enseignement oral de Plotin", Bulletin de la classe des Lettres et des Sciences Morales et Politiques de l'Academie royale de Belgique 23 (1937), p. 310-42.

62. Cf. p. 327: “As única conferências cujo texto se pode ter nas Notas de Amélio são as que foram pronunciadas antes $d$ 268, data em que Amélio parti de Roma para Apaméia. Ora, 0 tratados paralelos às Conferências da Teologia foram todos escritos antes dessa data. Eles pertencem todos aos primeiros períodos da atividade literária de Plotino.

63. Na coluna 507

64. C. D'Ancona, “The Arabic version of Enn. IV 7 [2] and its Greek model", citado na nota 50.

65. Encontra-se, portanto, na edição porfiriana, esta situação um pouco estranha, a saber, que recapitulação de IV 7 que abra IV 2 chega antes do texto que ela recapitula. Deve-se crer que o aspecto recapitulativo do início de IV 2 escapou a Porfírio, o que constitui no entanto uma falta editorial, ou pelo menos uma negligência.

66. É. Bréhier, apesar de publicar

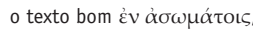
traduziu de modo errado: "entre os seres corporais".

67. 0 particípio $\alpha \dot{\phi} \varepsilon \tau \tau \varepsilon \varsigma$ apresenta uma certa ambigüidade, pois pode significar aqui tanto "rejeitar", "afastar" (trad. de Bouillet), quanto "abandonar" (trad. de Bréhier), ou "omitir",

"deixar de lado". 0 primeiro sentido nos parece preferível, pois não se vê bem por que, na recapitulação de IV 2, Plotino teria mencionado a enteléquia, se fosse para dizer que ele a omitiria enquanto que em 85 ele a rejeita.

68. Proclo, In Remp. I, p. 267. $22-28$ Kroll.

69. Proclus, Commentaire sur la Republique, Traduction et notes par A.-J. Festugière, II, Vrin, Paris, 1970 (Bibliotèque des textes philosophiques), p. 75 o árabe nos dá é um testemunho de que o texto eneádico antedatava o arquétipo...pode-se usar a versão árabe como um testemunho adicional para reconstruir, através da comparação com a citação de Eusébio, aquilo que o texto eneádico original poderia ter sido nas seções $B$ e C $]$.

Para irmos na mesma direção que Kraus e Schwyzer, nós lembraremos que existe uma prova objetiva do fato de a passagem sobre a enteléquia fazia com efeito parte das Enéadas. Na origem, na ordem cronológica, o tratado 2 [ =En. IV 7] vinha antes do tratado 4 [=En. IV 2]. Mas acontece que, nas Enéadas, IV 2 começa por um resumo que lembra as grandes conclusões de IV 7. Ora, esse resumo presume a enteléquia $^{65}$. Eis seu texto:

Buscando o que é a essência da alma, tendo mostrado que ela em nada é um corpo $[=I V 7,1$, $\left.8^{3}\right]$, e também que ela não é uma harmonia entre os incorpóreos ${ }^{66}\left[=8^{4}\right]$, tendo afastado ${ }^{67}$ a definição da alma como enteléquia porque ela não é verdadeira do modo como se a expõe e porque ela não indica o que é a alma $\left[8^{5}\right]$, e tendo dito que a alma participa com certeza da essência inteligível e da ordem divina [9-14], talvez possamos nós dizer alguma coisa mais clara sobre sua essência. No entanto, seria melhor seguir adiante".

A presença dessa recapitulação é uma prova indubitável de que o capítulo sobre a enteléquia pertence de fato na origem às Enéadas.

Enfim, Richard Goulet nos assinala um detalhe, que até aqui não foi, no nosso conhecimento, jamais levado em consideração para o problema que nos ocupa. No primeiro livro de seu Comentário sobre a República ${ }^{68}$, Proclo parafraseia uma passagem de Plotino:

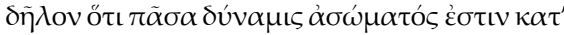

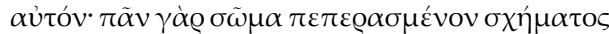

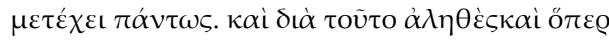

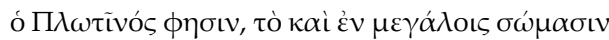

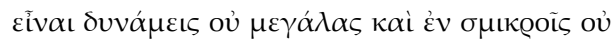

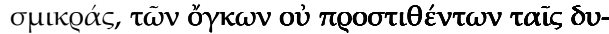

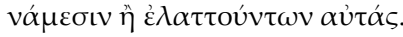

É evidente que toda potência é incorpórea segundo ele [= Platão]. Com efeito, todo corpo que tem limites participa, em toda hipótese, de uma figura. É por isso que é igualmente verdadeiro o que diz Plotino, a saber, que em corpos grandes há potências que não são grandes e que em pequenos há potências que não são pequenas, os volumes não acrescentando às potências nem as diminuindo.

A qual passagem de Plotino Proclo faz alusão? Kroll, o editor do comentário de Proclo, e Festugière, em sua tradução desse comentário ${ }^{69}$, remetem a uma passagem de IV 7. Ora, este se encontra precisamente na perícope $B$, que nós conhecemos somente por Eusébio. Eis o texto de Plotino:

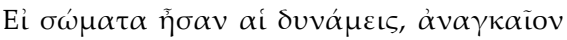

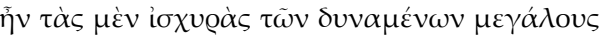

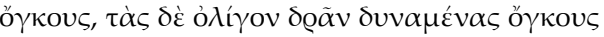

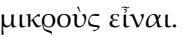

Se as potências fossem corpos, seria necessário que aquelas dentre as potências que são fortes fossem grandes volumes e que aquelas que são capazes de pouco agir sejam pequenos volumes.

Seria possivel sugerir-se que Proclo tinha essa opinião plotiniana dos Escólios de Amélio, que tinham registrado o ensinamento oral de Plotino. Em seu Comentário sobre o Timeu, Proclo relata com efeito uma teoria que Amélio

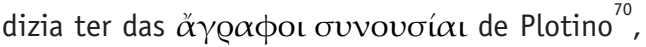
então não é impossível que ele mesmo tenha conhecido os cem livros de Escólios de Amélio ${ }^{71}$. Também não se poderia excluir que Amélio tenha falado dessa teoria em um de seus comentários. Vários testemunhos, entretanto, confirmam que Proclo dispunha da edição das Enéadas e que as comentou total ou parcialmente ${ }^{72}$. Lembremos aqui somente o Scholion sobre o título do De mysteriis de Jâmblico ${ }^{73}$, redigido por Miguel Pselo, em que

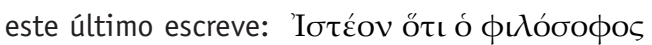

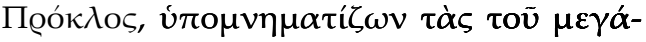

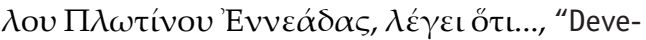
se saber que o filósofo Proclo, comentando as Enéadas do grande Plotino, diz que...", atestando assim que Proclo dispunha das Enéadas.

Temos, então, com essa citação por Proclo de uma passagem que não foi conservada senão por Eusébio, um indício suplementar de que a perícope $B$ 
de IV 7 pertencia mesmo às Enéadas. De fato, Henry conhecia esse texto de Proclo, ao qual ele remetia em seus États ${ }^{74}$ e do qual dizia: "Proclo faz alusão a essas linhas de Plotino", mas ele não parece tirar disso a conseqüência que se impunha. Ele escreve, no entanto ${ }^{75}$ : "essa citação prova que a grande lacuna da tradição direta é posterior ao VI ${ }^{\circ}$ s.". Era preciso ir mais longe. Essa citação convida a pensar que, se Proclo podia ainda ler a perícope B nas Enéadas, nada impede que Eusébio no IV ${ }^{\circ}$ s. tenha tido em mãos uma edição das Enéadas que comportava a passagem ausente da tradição direta, ou pelo menos não é necessário supor que Eusébio tinha uma versão pré-porfiriana dos tratados plotinianos.

Enfim, nós dispomos de um elemento concreto, que prova que Eusébio tinha mesmo em mãos as Enéadas, mas que jamais foi explorado neste contexto: em P.E. XV 10, ocorre que o título

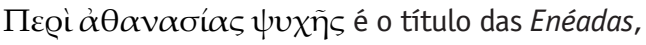
e não o do quadro cronológico, no qual a ordem das

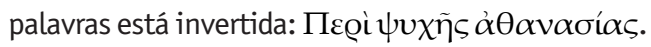
Como explicar que o extrato de Eusébio leve o título da edição porfiriana, senão admitindo que Eusébio tinha efetivamente em mãos essa edição?

Em conclusão, a P.E. de Eusébio nos revela uma grande lacuna, devida à queda de vários fólios, na tradição manuscrita da Enéada IV 7 (= perícopes B e C). Os editores Henry e Schwyzer tiveram razão em inserir em sua edição das Enéadas as duas passagens presentes somente em Eusébio. Assim, as três perícopes A, B, e $C$ se encadeiam perfeitamente. Plotino recusa sucessivamente as posições materialistas: a dos Estóicos que consideravam a alma um óöiá, mais precisamente como um pneu=ma, em seguida a posição pitagórica da alma como harmonia do corpo, enfim a posição aristotélica da alma como enteléquia do corpo organizado. As Enéadas, até o $V^{\circ}$ século e talvez além, comportavam com efeito as perícopes B e C. A presença das perícopes em Eusébio pode portanto explicar-se de modo outro que a utilização de uma edição pré-porfiriana e, por via de conseqüência, é absolutamente possível, senão provável, que os tratados plotinianos citados na P.E. provenham da recensão porfiriana.

\section{Outras hipóteses aventadas concernindo à proveniência dos tratados plotinianos}

J. Rist ${ }^{76}$, sugeriu que o material plotiniano consignado na P.E. de Eusébio podia provir dos exemplares de tratados plotinianos que Amélio, no início de 269, levara consigo em sua viagem a Apaméia da Síria (cf. V.P. 19. 19-27). Amélio devia ter levado um grande número de tratados, porque Longino, em uma carta endereçada desde a Fenícia para Porfírio, então em Lílibe na Sicília, diz a propósito dos tratados plotinianos: “Possuo todos quantos me parecem ser, mais os que agora me envias" (V.P. 19. 20), o que significa que Longino, em 269, conseguira fazer recopiar todos os tratados que the levara Amélio, bem como os que lhe tinha enviado Porfírio (a carta, com efeito, foi escrita depois de 269, data da partida de Amélio para Apaméia, e antes de 272, data da tomada de Palmira, onde Aureliano fez prisioneiro Zenóbia e seus conselheiros, Longino entre eles). Rist supõe que alguém, por exemplo, Pânfilo - o sacerdote que deu à biblioteca de Cesaréia as obras de Orígenes e as de outros autores eclesiásticos -, pudera conseguir para si os exemplares de Amélio, ou as cópias feitas por Longino, e que ele os pusera na biblioteca de Cesaréia, talvez depois de 270, data da morte de Plotino, ou pelo menos trinta anos antes de Eusébio escrever a Preparação. Acima de uma edição hipotética de Eustóquio, Rist privilegia a rede Amélio-Longino.

There may have been an edition by Eustochius, but there is no particular reason at all why Eusebius should have used it; after all it was probably issued in Italy. Much more likely, it seems to me, is that Eusebius' version derives either from the treatises in the hands of Amelius or from a copy of these or from some other source such as Longinus. Amelius, we recall, had a good deal, but not all, of Plotinus, and Eusebius knew the writings of Amelius, or at least his comments on John's Gospel. Perhaps the school of Amelius did indeed affect the Christian community at Caesarea, either in the time of Pamphilus or in that of Eusebius himself. This seems to be at least the likeliest alternative... But we should recall
70. Proclo, In Tim. II, p. 213.911 Diehl.

71. Cf. Vita Plotini 3.46-47; 4.5-6.

72. Ver R. Beutler, art. "Proklos", RE XXIII 1, 1957, col. 198, que indica esses diferentes testemunhos.

73. Esse Scholion figura no início da edição do De Mysteriis de Jâmblico por É. Des Places, p. 38

74. Henry, États, p. 111.

75. Ibid., p. 226.

76. Ver referência na nota 10 
that Amelius did not publish an edition of Plotinus: he had a collection of material. So there is no reason to suppose that all his material reached Eusebius. In fact Eusebius may well have know little if any more than the two treatises of Plotinus which he quotes" (p. 163-64) [Pode ter havido uma edição feita por Eustóquio, mas não há absolutamente nenhuma razão em particular pela qual Eusébio a teria usado; afinal, ela provavelmente foi lançada na Itália. Muito mais provável, me parece, é que a versão de Eusébio derive ou dos tratados nas mãos de Amélio, ou de uma cópia destes, ou de alguma outra fonte como Longino. Amélio, nós o lembramos, tinha bastante, mas não tudo, de Plotino, e Eusébio conhecia os escritos de Amélio, ou pelo menos seus comentários ao Evangelho de João. Talvez a escola de Amélio tenha de fato afetado a comunidade cristã em Cesaréia, seja no tempo de Pânfilo, seja no do próprio Eusébio. Essa parece ser, pelo menos, a alternativa mais provável...Mas devemos lembrar que Amélio não publicou uma edição de Plotino: ele tinha uma compilação do material. Portanto, não há razão para supor que todo seu material tenha chegado a Eusébio. Na verdade, Eusébio bem pode ter conhecido pouco ou nada além dos dois tratados de Plotino que ele cita].

P. Kalligas, retomando a tese de Rist, a desenvolveu e the conferiu um vigor maior num

77. P. Kalligas, “Traces of Longinus' Library in Eusebius' Preaparatio Euangelica", Classical Quarterly 51 (2001), p. 58498. Tenho que exprimir meu vivo reconhecimento a Paul Kalligas pela trocas amistosas que pudemos ter sobre esses problemas. Mesmo que, no fim dessas trocas, nenhum de nós tenha mudado fundamentalmente de opinião, pudemos assim explicitar nossas posições, o que já é cientificamente bastante positivo.

78. Ibid., p. 588

79. Sobre $\tau \dot{\alpha}$ que, nesse gênero de formulação, implicaria necessariamente mais de um Livro, e sobre a divisão de IV 7 em mais de livro, ver a seção 2 deste artigo. estudo recente, que merece toda nossa atenção ${ }^{77}$. Os dois tratados plotinianos que cita Eusébio, a saber, IV 7 e V 1, proviriam, segundo Kalligas, da biblioteca de Longino. Em sua carta a Porfírio (V.P. 19. 25-26), Longino evocava com efeito os tratados

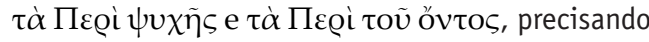
que ele os tinha feito copiar sobre os exemplares que Amélio the tinha levado, que ele tinha o mais vivo desejo de examiná-los, mas que eram os tratados mais faltosos que ele possuía. Apesar de seus títulos imprecisos em Longino, esses tratados poderiam, segundo Kalligas, ser identificados a IV 7 e V 1, isto é, precisamente aos dois tratados citados por Eusébio. 0 tratado IV 7, de que dispunha Eusébio no momento em que redigia os capítulos XV 10 e

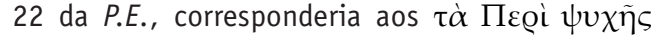
mencionados por Longino, ao passo que o tratado V 1, citado por Eusébio em P.E. XI 17, deveria ser

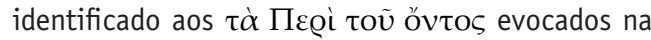

mesma carta. Para explicar como os dois tratados plotinianos chegaram a Cesaréia, Kalligas sugere que, após a queda de Zenóbia e a execução de Longino em 272, a biblioteca deste último, em Palmira, não teria sido transportada para Roma para enriquecer o triunfo de Aureliano, mas teria sido confiscada pelas forças de ocupação romanas e, assim, teria caído sob o controle do Estado romano. No início do IVo século, quando se preparava para terminar sua Preparação evangélica, Eusébio, que era próximo de Constantino, teria tido acesso a essa biblioteca de Longino, que continha as cópias dos tratados de Plotino feitas sobre os exemplares de Amélio. Assim, Eusébio teria conhecido, nessa época, uma seleção importante de obras platônicas dos dois séculos anteriores. 0 acesso a essa rica biblioteca explicaria por que, nos dez primeiros livros, Eusébio ataca os gregos como impostores e plagiadores, enquanto que a partir do livro XI ele adota uma atitude conciliadora e considera os gregos como pensadores sérios, notadamente Platão, que é apresentado como inteiramente digno de admiração. Kalligas, enfim, faz notar que os autores citados na P.E. XI-XV (Platão, certamente, notadamente as Leis e a República, Ático, Numênio, Plotino, Amélio, Porfírio, Severo, o próprio Longino) são aqueles que se espera encontrar na biblioteca de Longino, conselheiro da rainha Zenóbia em Palmira.

Toda essa hipótese repousa sobre a identificação proposta dos tratados mencionados por Longino (V.P. 19. 25-26). Essa questão merece ser examinada de perto.

- $\tau \dot{\alpha} \Pi \varepsilon \rho i \dot{\psi} v \chi \tilde{\eta} \varsigma /$ IV 7?

Kalligas ${ }^{78}$ propõe identificar os tratados

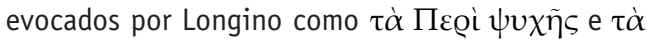

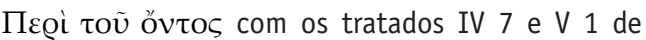
Plotino, respectivamente. Apoiando-se nessas duas constatações, cuja importância nós já contestamos mais acima ${ }^{79}$, ele faz notar que a expressão $\tau \dot{\alpha} \Pi \varepsilon \varrho \grave{i}$ $\psi v \chi \tilde{\eta} \varsigma$ corresponde a um tratado comportando mais de um livro, o que é o caso de IV 7 em Eusébio, a se

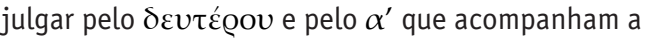
intitulação de IV 7 na P.E. XV 10 e 22; quanto ao fato de que o tratado IV 7 leva em Eusébio dois títulos diferentes (Пع@ì $\dot{\alpha} \theta \alpha v \alpha \sigma i ́ \alpha \varsigma \psi v \chi \tilde{\eta} \varsigma$ em XV 10 e 


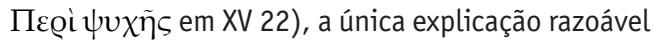
seria que ele tinha os dois títulos, um como seu incipit e o outro como seu explicit, o que em si não tão improvável quanto se possa pensar, uma vez que Plotino não dava, ele mesmo, títulos às suas obras e que estas podiam circular sob títulos diferentes (V.P. 4, 17-18). Kalligas conclui uma identificação que, aos seus olhos, se impõe: "It seems quite probable, then, that the work excerpted by Eusebius was none other than the treatise which had come into the possession of Longinus" [Parece totalmente provável, então, que a obra extraída por Eusébio não era outra que $o$ tratado que tinha chegado ao poder de Longino].

Mas Henry e Schwyzer ${ }^{80}$, em sua edição da Vita Plotini, tinham proposto identificar os tratados

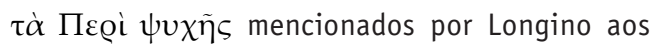
tratados IV 3, 4 e 5 de Plotino. Essa sugestão, que parece não ter chamado a atenção de Kalligas, nos parece credível. 0 título de Longino corresponde precisamente ao título que levavam esses três tratados no quadro cronológico da Vita Plotini (V.P. 5. 20-15), isto é, anteriormente à edição das Enéadas. No escólio à En. IV 4, 29. 55, que faz menção de toĭs Eủtoxíov, trata-se igualmente do segundo e do terceiro livro Пв@i $\psi v \chi \tilde{\eta} \varsigma$, ou seja, da Enéada IV 4 e 5. No quadro cronológico e no escólio, os tratados levavam então o mesmo título que em Longino, o que não é o caso do tratado IV 7, intitulado, no

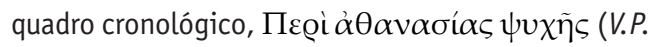
4. 25). Parece, portanto, legítimo identificar os tratados evocados por Longino à Enéada IV 3, 4 e 5, e distingui-los do tratado IV 7 citado por Eusébio.

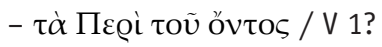

Kalligas propõe identificar os tratados $\tau \dot{\alpha}$

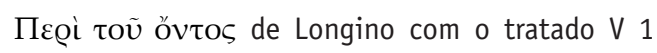
de Plotino. Mas Henry e Schwyzer ${ }^{81}$, de sua parte, tinham sugerido que eram os tratados VI 1, 2 e 3,

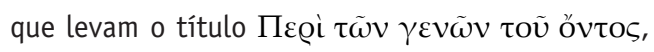

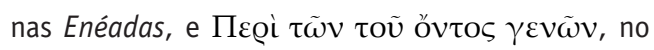

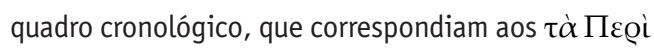

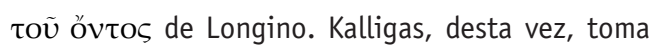
posição contra a sugestão de Henry e Schwyzer, aventando dois argumentos. Ele, de início, faz valer que VI 1-3 tratam das categorias do ser, e não do ser enquanto tal ${ }^{82} .0$ argumento tem apenas um alcance limitado. Não se lê, em VI 2, 1. 16-17: “Uma vez que fazemos uma busca sobre o ser ou sobre os seres, devemos de início distinguir entre o que nós, de nossa parte, chamamos o ser, sobre o qual nossa investigação poderia ser feita agora, e o que os outros pensam que é o ser - que nós chamamos aquilo que devém e que jamais é realmente ser"? Parece difícil negar que os tratados VI 1, 2 e 3: ПعQi

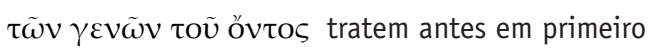
lugar do ser e que Longino possa ter-lhes feito

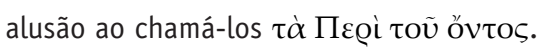

0 segundo argumento aventado por Kalligas contra a identificação proposta por Henry e Schwyzer é de ordem cronológica. Porfírio, em seu quadro cronológico, (V.P. 5, 51-55), data os tratados VI 1 , 2 e 3 de um pouco antes de sua partida de Roma, em 268. Lembrando que Porfírio, desde antes de sua partida para a Sicília, podia ter começado a revisão e a correção dos tratados que the confiara Plotino (V.P. 7. 51; 24. 2-3), Kalligas conclui que, se os

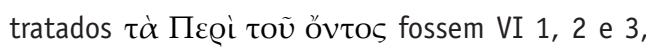
eles teriam sido revisados. Ora, Longino se queixa do caráter particularmente faltoso desses tratados. É por isso que Kalligas prefere identificar os tratados

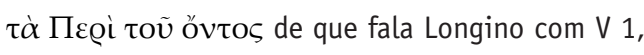
um tratado composto durante o período anterior à vinda de Porfírio (em 263), que era de fato o décimo na ordem cronológica.

0 argumento de Kalligas contra VI 1-3 poderia igualmente ser dirigido contra $V 1$, na medida em que Porfírio teria tido todo o tempo de corrigir igualmente este tratado mais antigo, fosse ele anterior à sua chegada a Roma. A missão aceita por Porfírio não implicava nenhuma restrição no corpus das obras de Plotino ${ }^{83}$. Por outro lado, não é certo que, mesmo corrigidos por Porfírio, os tratados de Plotino não tenham suscitado a mesma crítica da parte de Longino, pois Porfírio reconhece o caráter abrupto do estilo de seu mestre, e a qualidade que ele atribui às cópias de Amélio permite supor que ele sem dúvida não tinha o projeto de intervir a esse nível: “As cópias que ele [Longino] tinha adquirido a partir dos exemplares de Amélio, ele as julgava faltosas porque ignorava a maneira habitual de se exprimir do personagem [i. e. Plotino]. Pois, se havia
80. Cf. Editio minor, I, p. 23, em comentário à V.P. 19.25 e 26.

81. Cf. Ibid.

82. Kalligas, “Traces of Longinus' Library", p. 588, n. 25.

83. Ver V.P. 24.2-5: “Uma vez que ele mesmo nos confiou o cuidado de assegurar a organização e a correção de seus livros, e que prometi a ele, ainda vivo, cumprir essa tarefa e me comprometi também com outros companheiros..." 
cópias bem revisadas, essas eram justamente as de Amélio, por terem sido tomadas sobre os originais" (V.P. 20. 5-9).

Kalligas, aliás, tem o cuidado de responder a uma objeção que poderia ser feita à sua identificação: por que Longino teria intitulado

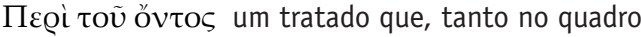
cronológico como nas Enéadas, leva o título Пع@i

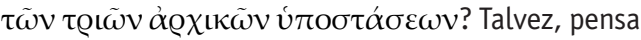
Kalligas, porque Longino, mais conservador e mais próximo das doutrinas medioplatônicas concernindo à natureza do Primeiro Princípio, era reservado em relação às teorias plotinianas (V.P. 19. 36-37); a teoria plotiniana das três hipóstases, notadamente a doutrina da transcendência do Uno em relação à realidade inteligível era acolhida com ceticismo no meio platônico contemporâneo. Ele teria, então, preferido não citar o tratado com um título assim contrário às suas convicções, ainda mais porque ele ainda não tivera a possibilidade de percorrer em detalhe o conteúdo desse tratado. Ademais, o fato de que os títulos não sejam obra do próprio Plotino podia incitá-lo a usar um outro título que aquele que conhecemos. Essa explicação é possível em teoria, mas nenhum indício concreto nos convida a pensar que 0 tratado tenha em algum momento levado um outro título.

A tese de Kalligas se apóia igualmente sobre a idéia de que o comportamento de Eusébio em relação a Platão teria evoluído a partir do livro XI da Preparação evangélica. Apesar de, nos dez primeiros livros, ele se mostrar assaz duro em relação a esses plagiadores que são os gregos, ele se põe a citar numerosas obras platônicas dos dois séculos anteriores numa atitude de espírito conciliador. Ora, uma tal reviravolta se explicaria de fato se Eusébio tivesse tido um acesso súbito a uma coleção de obras platônicas proveniente da biblioteca de Longino. Essa interpretação, em si muito interessante, merece também ela ser discutida. Antes do mais, notemos que Platão e os platônicos dos dois séculos anteriores a Eusébio já estavam bem presentes nos livros I a X da P.E. Mancheias de obras de Platão são citadas e Eusébio faz apelo a Porfírio diversas vezes (ele cita o De abstinentia, a Carta a Anébon, a Filosofia dos oráculos, o Tratado sobre as imagens, a Philologos akroasis e o tratado Contra os cristãos). Pode-se dizer que a atitude de Eusébio muda a partir do livro XI? Na realidade, Eusébio previra que a P.E. observaria um plano e nada fez senão ater-se a esse plano. Eis como Guy Schroeder, editor do livro VII da P.E. na coleção Sources Chrétiennes (Éditions du Cerf), define os objetivos de Eusébio (p. 15 de sua edição): “a) os livros I-VI refutam os politeísmos gregos e bárbaros, mostrando a absurdidade de seus mitos e o erro de suas doutrinas (oráculos, sacrifícios, destino); b) os livros VII-IX apresentam os hebreus e os judeus seus sucessores como os iniciadores da verdadeira filosofia; c) os livros X-XV confirmam a escolha em favor dos hebreus, que prevalecem sobre toda a filosofia grega: Moisés é ao mesmo tempo anterior e superior a Platão, que o plagiou". Não nos surpreenderemos, então, que seja sobretudo nos últimos livros consagrados especificamente à filosofia grega que Eusébio tenha feito apelo aos platônicos dos dois séculos precedentes. Ele podia dispor anteriormente de todas as obras desses filósofos, sem ter sentido a necessidade de servir-se dele tão massivamente, apenas e simplesmente porque ele ainda não tinha chegado ao momento em que deveria tratar da filosofia grega. Ademais, é verdadeiro que Eusébio, a partir do livro XI, encontra-se muito mais disposto com relação a Platão e aos platônicos do que nos livros precedentes? E preciso, mesmo assim, notar que, nos dez primeiros livros, sua opinião sobre Platão não era negativa. Em III 6. 7, ele atribui

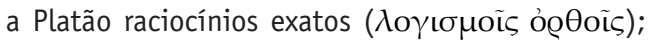
em V 4. 4, ele está de acordo com os que dizem que Platão, ao imaginar a matéria subjacente às qualidades aparentes dos corpos, livrou os filósofos de numerosos e graves dificuldades; e, em V 32. 2, ele qualifica a Platão $\gamma \varepsilon v v \alpha \tilde{i} o s$, nobre - o que é, todavia, um adjetivo bastante valorativo -, porque ele teve, a seus olhos, o mérito de banir Homero de sua República. A bem dizer, Eusébio sempre teve estima e admiração por Platão, mas é normal que seja nos livros em que trata da filosofia grega como tal e em que mergulha nos escritos platônicos, que ele tenha insistido maximamente na envergadura do pensamento do filósofo - que, contudo, permanece a seus olhos muito aquém de Moisés e dos hebreus. 
Sem excluir a priori que Eusébio possa ter tido um contato súbito com a biblioteca de Longino, temos dificuldade de reconhecer, a partir do livro XI da Preparação evangélica, uma mudança de atitude radical em Eusébio com relação a Platão e aos platônicos.

Portanto, não estamos convencidas de pelos argumentos que aventou P. Kalligas, mesmo que sua hipótese seja engenhosa e teoricamente possível. Uma das conseqüências que se pode tirar de sua interpretação é que Eusébio seguia um texto diferente das Enéadas. Ora, nós mostramos que nenhum dos argumentos que vai contra a utilização das Enéadas por Eusébio resiste à análise. Do mais, essa tese restringe a difusão dos tratados de Plotino a uma só via de transmissão: os tratados que Longino fez copiar sobre os exemplares de Amélio ${ }^{84}$. Mas seria falso imaginar que os tratados plotinianos conhecessem no Oriente, no IV $^{0}$ s., apenas uma difusão assim confidencial. Eunápio de Sardes afirma o contrário, no fim do IV ${ }^{\circ}$ S., nas suas Vidas dos filósofos e dos sofistas: "Os livros de Plotino não estão com mais freqüência que os diálogos platônicos somente nas mãos das pessoas cultivadas, mas a massa numerosa, mesmo que compreenda de modo equivocado as doutrinas, inclina-se diante deles $^{\prime{ }^{85}}$. Mesmo supondo que Eunápio exagere um pouco e que os escritos plotinianos tenham sido mais conhecidos nessa época em meios pagãos do que em meios cristãos, manifestamente os tratados de Plotino circulavam no Oriente no IV $^{\circ} \mathrm{s}$.

\section{Conclusão}

Nenhuma razão sólida permite manter a hipótese de uma versão pré-porfiriana para explicar a proveniência das cópias dos tratados plotinianos de que dispunha Eusébio, no momento da redação dos livros XI e XV da Preparação evangélica. Se deixamos de lado a hipótese, sempre possível, de uma compilação preexistente em que Eusébio poderia ter encontrado os extratos que ele cita, como é o caso para um bom número de passagens mencionadas na Preparação evangélica, a hipótese das Enéadas é a que hoje se impõe com força em razão notadamente do testemunho da Pseudo-Teologia de Aristóteles, ao qual vem juntar-se ï de Proclo em seu Comentário sobre a República. Nós constatamos que todos os argumentos que se opunham a que Eusébio tenha tido em mãos as Enéadas podiam ser refutados, notadamente aquele da suposta divisão de IV 7 e o da grande lacuna desse mesmo tratado, e que aqueles que pretendiam apoiar a presença de uma edição pré-porfiriana em Cesaréia, no tempo de Eusébio, não eram determinantes. Como parece estabelecido que, no $V^{0}$ s., circulava ainda uma edição das Enéadas que tinha um texto completo do tratado IV 7 - cujo título, aliás, Eusébio cita na versão das Enéadas -, nada impede que, no IVo s., Eusébio tomado o texto dos tratados que ele cita da edição Enéadas ${ }^{86}$.
84. Encontrava-se em Rist a idéia de que Eusébio podia conhecer apenas os dois tratados que cita. Essa idéia é retomada por Carrike The Library of Eusebius of Cesarea, p. 108-12. Outras proveniências além da de Longino podem, a propósito, ser imaginadas. Por exemplo: R. M. Grant, “Porphyry among the early Christians", em W. den Boer et. al. (ed.), Romanitas et Christianitas, Mélanges J. $\mathrm{H}$. Waszink, North Holland Publishing Company, Amsterdam, 1973, p. 171-88, tinha sugerido que um certo Anatólio, discípulo de Porfírio, ao qual este dedicou duas Questões homéricas, e que foi o primeiro a mestre de Jâmblico (Eunápio, Vidas dos filósofos e dos sofistas V 1, 2), podia ter introduzido na biblioteca de Cesaréia as obras de Porfírio. Ele também poderia ter feito entrar nela tratados plotinianos!

85. Eunápio, Vidas dos filósofos e dos sofistas III 3, p. 5.23-5.3 Giangrande.

86. Pânfilo, que fizera numerosas aquisições para a biblioteca de Cesaréia, pode ter feito entrar um exemplar das Enéadas antes de sua morte como mártir em 16 de fevereiro de 310 . 